Party System Transformation and the Structure of Political Cleavages in Austria, Belgium, the Netherlands and Switzerland, 1967-2019

Carmen Durrer de la Sota

Amory Gethin

Clara Martínez-Toledano

March 2021

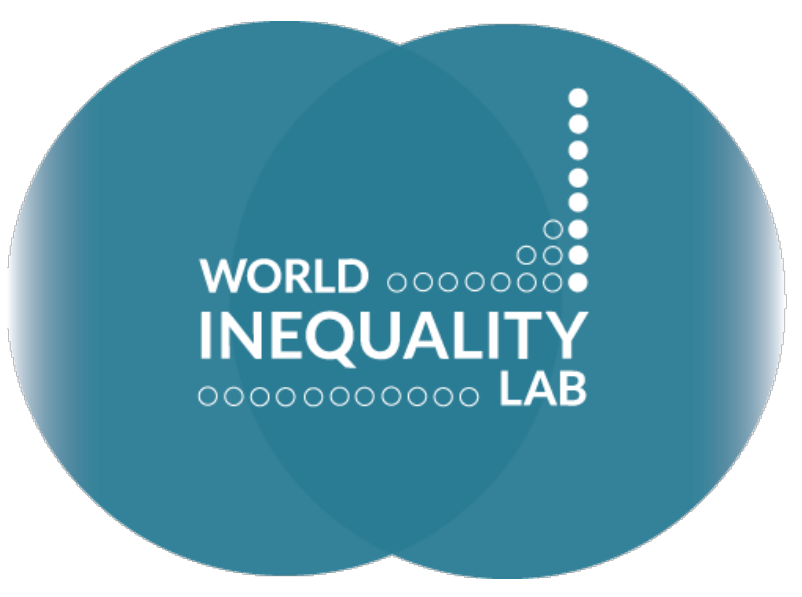

WID.WORLD

THE SOURCE FOR

GLOBAL INEQUALITY DATA 


\title{
Party System Transformation and the Structure of Political Cleavages in Austria, Belgium, the Netherlands, and Switzerland, 1967-2019*
}

\author{
Carmen Durrer de la Sota \\ Amory Gethin \\ Clara Martínez-Toledano ${ }^{\dagger}$
}

\begin{abstract}
This paper combines post-electoral surveys to study the transformation of the structure of political cleavages in Austria, Belgium, the Netherlands, and Switzerland over the last five decades. Despite their history of linguistic, regional, and religious conflicts, all four countries share a common tradition of consensus decision-making, which has remained until the present. Yet, the weakening of historical cleavages, the emergence of new political formations (i.e. Green parties on the left and anti-immigration parties on the right), and the rise of new divides have significantly transformed their party systems since the 1980s. Support for green and left-wing parties among highest-educated voters, and for anti-immigration parties among the lower-educated has grown, while top-income earners have remained instead more supportive of the traditional right. Both the rise of new green and anti-immigration parties, but also changes within old parties have thus led to the emergence of "multi-elite party systems", as it has been shown in other Western democracies.
\end{abstract}

\footnotetext{
* We are grateful to Gabriel Gazeau and Thomas Piketty for their useful advices.

$\dagger$ Carmen Durrer de la Sota, Amory Gethin: Paris School of Economics - World Inequality Lab. Clara MartínezToledano: Imperial College London - World Inequality Lab.
} 


\section{Introduction}

How has the emergence of new movements and ideologies transformed socioeconomic conflicts in Western Europe in the past fifty years? This paper approaches this question by documenting the evolution of political cleavages in Belgium, the Netherlands, Switzerland, and Austria. These four countries provide interesting case studies to understand sources of political change in advanced democracies, as their party systems have undergone an exceptionally deep process of realignment and fragmentation. Having been torn apart by linguistic, regional, and religious conflicts, they share a common history of consensus decision-making, and are often considered to be archetypical examples of consociational democracies, where the interests of antagonistic "pillars" were mediated by power-sharing agreements between the different parties. This cooperative dimension of democratic politics has remained a common feature of these four democracies, but the weakening of historical cleavages, the emergence of new political streams, and the rise of new divides have significantly transformed their party systems (O’Leary 2020).

The 1980s and subsequent decades saw the proliferation of new political parties and a remarkable complexification of the political landscape. Green parties on the left and antiimmigration parties on the right, in particular, have increasingly challenged traditional Christian-democratic, conservative, liberal, social democratic, and socialist forces. This evolution was most radical in Switzerland, where the far right (the Swiss People's Party) and the greens (the Green Party and the Green Liberal Party) now top the polls. While this is not yet the case in Belgium, the Netherlands, and Austria, a comparable disintegration of historical party systems has taken place, and a similar scenario could well arise in the future.

One of the most striking transformations of political cleavages in Western democracies has been the reversal of the education cleavage and the emergence of "multi-elite party systems": while the "right" continues to be supported by top-income voters, highest-educated voters have gradually shifted from the "right" towards the "left" (Piketty 2018; Piketty \& Kosse 2019; Bauluz, Gethin, Martínez-Toledano \& Morgan 2021; Gethin 2021). The main finding 
of this paper is to show that the exact same reversal of the education gradient took place in Belgium, the Netherlands, Switzerland, and Austria, though with interesting variations. In two-party systems such as the United States or the United Kingdom (Piketty 2018), this shift has essentially taken place within the main parties. In the four countries studied in this paper, by contrast, the decline of traditional parties and the rise of new parties allows us to contrast new and old forces, and hence to shed light on the emergence of multi-elite party systems. Our results show that it was not only the rise of new green and anti-immigration parties, but also changes within old parties, which drove the shift of higher-educated voters towards leftwing parties.

Belgium's historical regionalization of politics has persisted until today and there are strong differences in support for traditional parties between Flanders and Wallonia. The Socialists are mainly supported in Wallonia, whereas the Liberals and the Christian Democrats are more popular in Flanders. Despite these regional divides, we still observe the same transition towards a multi-elite party system as in other Western countries. New actors have played the most decisive role in this process: green parties have become increasingly popular among university graduates, while Flemish nationalists have received growing support from lowereducated voters. The reversal of the education cleavage however does not seem to have fully occurred yet, which could be explained by the ability of far-left and socialist parties to still gather an important share of the lower educated, while at the same time having succeeded at preventing the emergence of the far right in Wallonia until now.

In the Netherlands, too, the emergence of a multi-elite party system has been associated with the rise of new liberal (D66), environmentalist (GroenLinks), and anti-immigration (the Pim Fortuyn List and the Party for Freedom) forces. This transformation has led to an exceptional fragmentation of the Dutch party system as well as to an early reversal of the education cleavage, with higher-educated becoming more likely to vote for left-wing and centrist parties as early as the 1980s. Socialists and Social Democrats continue to attract some sections of their traditional constituencies, but they have seen their vote shares collapse and are now competing with the Party for Freedom in the representation of the low-income and lower- 
educated electorate. In addition to the sociocultural and environmentalist issues promoted by the Liberals and the Greens, a new nativist cleavage has emerged, mirrored by the massive support of Muslim voters for the left (or against the right), which has contributed to the blurring of traditional class and religious (Catholic vs. Protestant) cleavages in recent years.

Switzerland is the country where the shift of the higher educated towards the left has been the most dramatic. This can be explained by the surge of the greens and the far right, but also by the transformation of historical parties. The Swiss People's Party, now the most successful anti-immigration force in Europe, has proved to be exceptionally popular among lowereducated voters in rural areas, while the greens have captured a growing share of the highereducated vote in urban areas. Socialists and communists have nonetheless undergone a profound transformation too, and now make their best scores among the higher educated. In contrast to Belgium, language divisions have played a rather small role in Swiss federal elections and have weakened over time, as the Swiss People's Party, historically tied to German-speaking Switzerland, has gained increasing support in the French- and Italianspeaking regions.

Finally, in Austria, we find that the emergence of a multi-elite party system has in part been driven by the emergence of the Greens in the 1980s, disproportionately supported by university graduates in urban areas, as well as by the decreasing support for the Social Democratic Party among lower-educated voters. However, it has been the remarkable transformation and growing success of the Freedom Party, from a German-nationalist party to a powerful anti-immigration party, which has decisively led lower-educated voters to move towards the right. As in the Netherlands, this evolution has been accompanied by the advent of a new nativist cleavage, with Muslim voters being substantially more likely to vote for leftwing and liberal parties. 


\section{Belgium}

The Democratization Process after the Revolution

The origins of modern-day Belgium date back to the end of the Napoleonic era. After the fall of the French Empire in 1815, the Low Countries found themselves briefly reunited under Dutch rule. However, in 1830, the Belgian Revolution led to the secession of the southern provinces from the rest of the Netherlands and the creation of an independent Kingdom of Belgium. The unrest that sparked the revolution was mainly instigated by the French-speaking Catholic bourgeoisie, that rejected the preeminence of the Dutch language and of Calvinism associated with Dutch rule. The Flemish lower bourgeoisie, that was more Catholic than Flemish, supported this anti-linguistic movement (Beaufays 1988). These socio-economic, regional, religious, and linguistic divisions have persisted over time and characterize Belgian society today.

The revolution was a success and Belgium became a French-speaking parliamentary monarchy through the 1831 constitution. The bourgeoisie took over power and the political foundations of economic liberalism were put in place. The two main parliamentary groups at the time were the Liberals and the Catholics. Over the course of the $19^{\text {th }}$ century, a progressive middle-class movement began contesting the dominance of the upper classes and established links with a fast-growing socialist movement, which gave rise to the Socialist Party in 1885 . The proletarian movement and the bourgeoisie found a compromise with the introduction of male universal suffrage in 1894 (Witte 2009). During the same period, a Flemish emancipation movement emerged seeking equal status for Dutch speakers in the Belgian state. As a result, new Flemish nationalist parties were formed by Liberals and Christian Democrats. After a pacific start, the movement became increasingly radical in the aftermath of World War I. With the onset of the Great Depression in the 1930s, existing parties shifted to the right and fascist groups emerged. However, after the Second World War the extreme right was widely discredited for its collaboration with the Nazis during the German occupation and it disappeared from the political scene. In contrast, the Communist 
Party, founded in 1921 and identified with the resistance, grew considerably in the years after the war, taking part in coalition governments between 1944 and 1947. However, its growth was short-lived, mainly due to the rise of an anti-communist sentiment during the Cold War (Winter and Dumont 1999). The composition of the government thus continued to fluctuate between the Christian Democrats, the Liberals, and the Socialists, although from the 1950s onwards the Christian Democrats maintained a continuous presence in power, often in coalition with the Socialists (Figure 1). At the same time, the Flemish movement regained strength and a new nationalist Flemish party, the People's Union (Volksunie, VU), was founded in 1954.

With its entry into the European Economic Community in 1957, Belgium embarked on a period of economic growth. The market for Belgian products expanded and an ambitious plan for regional economic development was launched by the Socialist-Christian coalition in 1959. While Flanders attracted increasing foreign investment, Wallonia's heavy industry kept alive with large state subsidies. Economic disparities between the two regions exacerbated, which intensified both sides' dissatisfaction with the centralized state system. Some Flemish were against subsidizing a weak regional economy with a decadent industry, while some Walloons feared that the more numerous and prosperous Flanders would soon dominate the state (Deprez and Vos 2016).

Following massive strikes, a linguistic border was established in 1962 that split the country into zones of exclusive language use and a new special arrangement was introduced for the bilingual area around Brussels. The slow process of federalization continued with the parliament approval of cultural autonomy to the regions of Flanders and Wallonia in 1971. It culminated with the St. Michael's Agreement in 1992, after which the establishment of the federal state was embraced in the new constitution of 1994 (Deschouwer 2012). The acceptance of federalism in place of separatism by the VU in the late 1970s was disapproved by a right-wing faction of the party, who formed the Vlaams Blok (dissolved and recreated as Vlaams Belang in 2004). This nationalist anti-immigrant political party gained increasing 
support during the 1990s, a period during which Belgium's immigrant population grew significantly (Rink, Phalet, and Swyngedouw 2009).

Together with the new nationalist parties, the party system was broadened between the 1960s and 1980s with the split of the three traditional parties - the Christian Social Party, the Liberal Party, and the Socialist Party - along linguistic lines. Moreover, the two environmental parties, Ecolo in Wallonia and Agalev (now Groen) in Flanders, were founded in 1980 and 1982 respectively. Hence, the only major political party that operates since then as a single Belgian party is the left-wing Worker's Party (Parti du Travail de Belgique (PTB) in French, Partij van de Arbeid van Belgie (PVDA) in Flemish) founded in 1979, that considered the politics of the existing Communist Party of Belgium had turned too social democratic. In 2001, another Flemish nationalist party, the New Flemish Alliance (Nieuw-Vlaamse Alliantie, $\mathrm{N}-\mathrm{VA}$ ), was formed by members of the right-leaning faction of the VU.

The high fragmentation of the party system has made establishing stable governing coalitions increasingly hard. In 2007, the Flemish Christian Democrats won the parliamentary elections but failed to form a large enough coalition. After six months of political deadlock, a new coalition government made up by Walloon and Flemish parties finally took power in 2008. Following the withdrawal of the Flemish Liberals and Democrats, however, anticipated elections were held in 2010. The big winners were the separatist New Flemish Alliance and the French-speaking Socialists, but they were unable to come to an agreement to form a coalition. After 530 days without a government, Belgium entered in 2009 into a debt crisis together with many other European countries.

In 2011, after 541 days without a government, a big coalition of Christian Democrats, Liberals, and Socialists was eventually formed, amid the unfolding Eurozone crisis. Elio Di Rupo became Belgium's first Socialist prime minister since 1974 and the first Francophone prime minister in more than three decades. The country then entered a period of relative political stability, but the tension between the country's north and south remained. In the 2014 election, after five months of discussions, a Flanders-focused center-right coalition was 
formed that excluded the Socialists from the government for the first time in more than two decades. In the 2018 election, traditional parties suffered further losses in both regions. The Vlaams Belang resurged in Flanders, and with the N-VA, both Flemish separatist and nationalist parties, obtained nearly half of the total vote in Flanders. Meanwhile, the far-left PVDA/PTB and the Ecolo rose in Wallonia.

\section{The Emergence of a Multi-Elite Party System and the Regional Divide}

How has the transformation of Belgium's party system after federalization shaped the reversal of the educational cleavage and the emergence of a multi-elite party system? How have historical economic, linguistic, regional, and religious divisions shaped political behaviors until today? In what follows, we analyse the evolution of the vote along these socio-economic dimensions using political attitudes surveys covering all federal elections held in Belgium between 1971 and 2014. ${ }^{1}$

Figure 2 shows the relative support for the Socialists and Ecologists among highest-educated and top-income voters since 1971. Grouping these parties together allows us to track a consistent group, which has received between 30 and 40 percent of votes in most elections since 1945. While highest-educated voters were less likely to vote for the left by 11 percentage points in the 1970s, in the last two elections they were as likely to do so as the rest of the electorate. In contrast, top-income voters have remained more likely to support the right over the whole period. Hence, Belgium seems to have been moving towards a multi-elite party system, but this transformation has not fully taken shape: the gap in left vote between higher-educated and lower-educated voters seems to have stabilized around zero, in comparison to the other countries studied in this paper where it has become strongly positive (see below).

\footnotetext{
${ }^{1}$ See appendix Table A1 for data sources.
} 
To understand the drivers of the education and income gradients, it is useful to replicate the previous analysis for each of the main left-wing and right-wing parties or coalitions. Four parallel dynamics appear to have driven these changes. ${ }^{2}$ First, the emergence of the environmental parties in the 1980s, supported by young university graduates in urban areas, strongly contributed to the reversal of the educational cleavage. Second, the traditional left has, however, remained relatively more supported by the lowest-educated voters throughout the whole period, which explains why this reversal has not been fully completed. Third, the rise of the Vlaams Blok, mainly supported by less educated voters, has absorbed the decline in the low-educated vote to the Christian Democrats. Fourth, the stability of the income gradient is largely due to the persistence of the vote for the Liberals among top-income earners and for the Socialists among low-income earners.

Belgium has long been considered a clear example of consociational democracy, in which linguistic, regional, and religious interests have been mediated through power-sharing agreements between the different parties (Deschouwer 2006). These historical divides have persisted until today and there is a strong division in the vote for traditional parties between Flanders and Wallonia. The Socialists are mainly supported in Wallonia, whereas the Liberals and the Christian Democrats are more popular in Flanders. All three traditional parties used to be strong in Brussels, but since the 2000s support for the Socialists has considerably grown in the capital city, leading to a strong reversal in the left-right cleavage (Figure 3). The vote for environmental parties is less regionally concentrated, as they are popular among highereducated voters across all Belgium. Belgium's strong regional division of the vote is unique in comparative perspective, in that even the historically unitary traditional parties are split along linguistic lines, contrary to what is observed in other Western countries with regional nationalist parties and/or marked linguistic divides, such as Canada, Spain, or Switzerland (see below).

\footnotetext{
${ }^{2}$ See Figure AC16 in the appendix.
} 
A strong differentiation of the vote is also prevalent along religious lines (Table 1). The Protestant minority is more inclined to vote for the Socialists, whereas Catholics are more supportive of the Christian Democrats. Green parties attract more votes among non-religious voters. In line with what we observe in other Western democracies, Muslims vote massively for the left.

Overall, despite Belgium's extraordinary regionalization of politics, we still observe the same transition towards a multi-elite party system as in other Western countries. The regional dimension does still play a role, however, as the lowest-educated extreme right is concentrated in Flanders. The absence of a strong extreme-right party in Wallonia has been often related to the creation of a successful cordon sanitaire by mainstream parties and the media, that did not happen in Flanders (Jonge 2020). This has arguably contributed to the persistence of a powerful lower-educated left in Wallonia, whose strength has acted as a counteracting force preventing the complete reversal of the educational cleavage.

\section{Netherlands}

\section{The Emergence of the Dutch Political System}

The history of the Netherlands as a sovereign state begins in 1648, when the seven northern provinces of the Low Countries were granted independence after defeating the Spanish in the Eighty Years' War. However, the country remained in practice little more than an alliance of widely autonomous provinces until the French Revolution. In 1795, with widespread support of the local population, the French transformed the confederacy into a highly centralized, democratic republic. Several coups d'état ensued until Napoleon decided to appoint his brother Louis as king in 1806, thus transforming the country for the first time in its history into a kingdom. After the fall of Napoleon in 1815, both centralism and monarchy, foreign to Dutch tradition, were preserved. 
The wave of liberal revolutions that swept Europe in 1848 prompted a preemptive reform of the constitution, which is considered to mark the beginning of modern Dutch democracy. A system of parliamentary monarchy was adopted, although suffrage remained censitary. In 1917 , the right to vote was finally extended to all men and two years later to women as well. The Pacification of 1917, as it became known, also introduced the single district proportional rule, an idiosyncratic characteristic of the modern Dutch electoral system. Since then, the entire country has been considered as a single constituency, with no electoral threshold to enter parliament, which has enabled the emergence and survival of small parties.

With the advent of democracy, the political system came to reflect the deep cleavages of Dutch society. Since its independence from the Spanish Empire, the country faced a major internal religious division. The Reformation had seen enormous success across the Dutch provinces, however, the Spanish presence in the southeastern parts of the territory during the Eighty Years' War assured the survival of Catholic bastions within the country. In addition, the Dutch Reformed Church experienced several splits over the $19^{\text {th }}$ century, leaving a society widely fragmented on the basis of religion. At the time of the industrialization of the country in the 1870 s and 1880 s, the religious divide hampered the development of a strong workingclass movement, yet a class cleavage still emerged among the secular segments of the population (Andeweg and Irwin 2005).

The social groups defined by the religious divides and, to a lesser extent, by the class cleavage were significantly isolated from one another. Catholics in particular had a separate school system, a labor union, media outlets, and even a healthcare network. The strength of the divisions led to consider these social groups as full right subcultures, called "pillars" (zuilen).

Scholars distinguished three to five pillars: on the religious dimension, a Catholic one and one to two Protestant ones; on the class dimension, a Socialist one and, "only by default" (Andeweg and Irwin 2005), a Liberal one. The degree of integration varied widely across pillars, with the Catholics constituting by far the most homogeneous group, and the Liberals the most disperse (Lijphart 1975). Yet, to each pillar corresponded a party or group of parties: 
the majority of Catholics voted for the predecessor of the Catholic's People's Party (Katholieke Volkspartij, KVP), the Protestants either for the Anti-Revolutionary Party (AntiRevolutionaire Partij, ARP) or the Christian Historical Union (Christelijk-Historische Unie, $\mathrm{CHU}$ ), and the secular working class for the predecessors of the Labor Party (Partij van de Arbeid, PvdA) and to a lesser degree for the Communist Party (Communistische Partij Nederland, CPN). The liberal vote remained quite split until the formation of the People's Party for Freedom and Democracy (Volkspartij voor Vrijheid en Democratie, VVD) at the end of the Second World War (Andeweg and Irwin 2005). Voters, of course, did not always vote according to their pillar, and vote shares still fluctuated. Fragmentation was high, and it was overall clear to all political forces that they would remain a minority. This contributed to the emergence of a culture of consensual politics, making of the Netherlands the archetype of a consociational democracy.

\section{The Decline of Traditional Cleavages and the Rise of Anti-Immigration Parties}

The height of pillarization and political stability came at the end of the Second World War (Lijphart 1975). For over two decades, electoral volatility was very low despite the large number of parties (Figure 4). However, by the end of the 1960s, wide societal changes and the rise of new values quickly transformed the political scene. A process of depillarization unfolded, primarily attributed to the increasing secularization of Dutch society (Kriesi 1989).

New parties emerged, embodying social liberal and so-called New Left values, most notably Democrats 66 (Democraten 66, D66) and the Political Party of Radicals (Politieke Partij Radikalen, PRR) (Bornschier 2010; Kriesi 210). The latter would merge in 1990 with the Communist party and other small left-wing parties to form GreenLeft (GroenLinks, GL). The process of secularization severely weakened the Christian parties, which until the 1967 election had continuously held a majority of seats in the parliament. As a means to regain some strength, the three main Christian parties, the KVP, the ARP, and the CHU formed an alliance in 1973 and eventually merged into the Christian Democratic Appeal (ChristenDemocratisch Appèl, CDA) in 1980. The party's core appeal became its attachment to 
traditional values and its opposition to core liberal demands, in particular the legalization of euthanasia, abortion, and the rights of sexual minorities.

Despite the arrival of new parties in parliament, consensual politics remained a key feature of the Dutch system (Lijphart 1989). Over the next decades, all major parties eventually shared a coalition government. The configuration of the alliances was highly variable, depending more on the key polarizing issues and the electoral performance of the different parties in each election, than on long-lasting agreements. As in many other Western democracies, sociocultural issues progressively gained weight, to the detriment of economic concerns. This culminated in the formation in 1994 of a grand coalition purple government uniting the social democratic PvdA and the conservative-liberal VVD, which had historically held opposite views on economic issues, together with the smaller D66. The coalition, led by the PvdA Prime Minister Wim Kok, was repeated in 1998 and made of the Netherlands the first country to legalize euthanasia and gay marriage (Andeweg and Irwin 2005).

However, under the image of consensus and stability, discontent with the grand coalition was growing and anti-immigration sentiments were gaining in popularity among the electorate. The unrest that had been building up finally broke into the political system in the "long year 2002" with the arrival of a new political figure, Pim Fortuyn. He incarnated the idea that immigration had gone too far in the Netherlands, and that the political elite had neglected the needs of the Dutch (Aarts and Thomassen 2008). A few days before the election, he was assassinated by an animal rights activist, which constituted the first political murder in the country in 330 years. His party, the Pim Fortuyn List (LPF), nonetheless saw an unprecedented success for a new party in the Netherlands, gathering 17 percent of the votes. The LPF was included in the governing coalition, but without its leader, it quickly started disintegrating and lost most of its support in the 2003 elections (Andeweg and Irwin 2005).

After this brief recess, anti-immigration forces resurged with the founding of the Party for Freedom (Partij voor de Vrijheid, PVV) by Geert Wilders, former member of the VVD, in 2004. A "one-man party", the PVV quickly gained electoral support, nourished by the same 
discontent with Dutch multiculturalism that had propelled the LPF's success (Vossen 2016). Interestingly, however, anti-immigration, anti-Islamic, and anti-EU stances are possibly the only common trait between the PVV and the LPF and their European counterparts, as these two parties have simultaneously held progressive stances on social matters (Van Holsteyn 2018). In defending a "national culture" they have set to defend abortion rights, the rights of sexual minorities (Pim Fortuyn was indeed openly gay), as well as the legalization of euthanasia. However, it is important to note that these issues are no longer a relevant point of political competition in the Netherlands, due to their widespread acceptance (Aarts and Thomassen 2008).

In parallel to the rise of anti-immigration forces, the 2000s also witnessed the growth of the Socialist Party (Socialistische Partij, SP), a small party to the left of the PvdA, which reached 16.6 percent of the vote in 2006, thus becoming temporarily the third largest force in parliament. However, the party has since lost much of its earlier gains, obtaining only 9 percent of the vote in the last elections. Simultaneously, the ideologically close GreenLeft has seen a moderate progress, reaching a similar level of support.

\section{The Emergence of a Multi-Elite Party System and the Decline of Old Divides}

How did these radical changes in the Dutch party system translate into electoral choices? Using available post-electoral surveys, we are able to track electoral behaviors in the Netherlands in all federal elections held between 1967 and $2017 .^{3}$

As in most Western democracies, the Netherlands has transitioned to a multi-elite party system in the past fifty years. Figure 5 shows the support for left-wing and centrist parties, including the Social Democrats (PvdA), Democracy66 (D66), the Socialist Party (Socialistische Partij, SP), GreenLeft (GroenLinks, GL), and other small left-wing parties among highest-educated and top-income voters in parliamentary elections since 1967. Support

\footnotetext{
${ }^{3}$ See appendix Table CA1 for data sources.
} 
for these parties among the intellectual elites has increased significantly over the past decades. While highest-educated voters in the 1960s-1970s did not vote for left-wing and centrist parties any more than the rest of the electorate, by the 2010s they had become 10 percentage points more likely to do so, after controlling for other socioeconomic factors. Meanwhile, topincome voters have remained consistently more likely to vote for the People's Party for Freedom and Democracy (VVD), with no clear trend. The shift of highest-educated voters towards socialist, social-democratic, liberal, and green parties is, however, smaller than in other countries addressed in this paper, partly due to the fact that D66, notorious for its success among higher-educated voters, had already entered the political arena in 1966 . The Netherlands thus represents a case of a relatively early transition to a multi-elite party system. Nevertheless, the reversal of the education cleavage has not completely reached the Social Democrats (PvdA) and the Socialist Party (SP) yet, which still find greater support among primary-educated voters than among university graduates, aside from an exceptional period during the 2000s. The emergence of a multi-elite party system has thus been strongly driven by new parties, with the GreenLeft (GL) and D66 making better scores among university graduates and Geert Wilders' Party for Freedom (PVV) being substantially more popular among primary-educated voters. ${ }^{4}$

Besides income and education, Dutch post-electoral surveys are unique in having consistently asked respondents to self-identify on a comparable, detailed social class scale since the 1960s, which allows us to have a particularly granular perspective on the link between voters' selfperceived social-class and their partisan affiliation. These data reveal a sharp decline in class cleavages: self-identified working-class voters were more likely to vote for left-wing and centrist parties by nearly 25 percentage points in the 1960s and 1970s, while they are now only marginally more likely to do so (Figure 6). This shift has been largely driven by the rise of new parties, as the class profile of most parties has proved to be highly resilient over time. ${ }^{5}$

\footnotetext{
${ }^{4}$ See appendix Figure BC17.

${ }^{5}$ See appendix Figure BC19.
} 
The transformation of political cleavages in the Netherlands has thus been facilitated by the extraordinary fragmentation of its party system, a fragmentation arguably enabled and encouraged by its system of proportional representation. In this context, the Dutch case turns out to be particularly interesting to understand sources of political change in Western democracies, as it enables us to precisely distinguish the electorates of the different political movements which often unite under the banner of single parties or coalitions in less fragmented systems.

Table 2 addresses this question by showing the decomposition of the vote for all major parties by income, education, self-perceived social class, rural-urban location, and religion in the past decade. Together, these five socioeconomic dimensions appear to differentiate very clearly the electorates of political parties in the Netherlands. The Socialists (SP) and the Social Democrats (PvdA) embody the legacy of old class cleavages, and make better scores among low-income, lower-educated, and self-identified working-class voters. Meanwhile, the conservative-liberal VVD and the social-liberal D66 are largely supported by high-income, higher-educated, upper-class voters, with the latter drawing an even larger share of its support from urban, secular elites. The Christian CDA, the third big descendant of the postwar party system, has a primarily rural and religious electoral base, appealing in particular to Catholic and Protestant voters in the countryside. Education and location appear to be the strongest predictors of support for GreenLeft, who, like D66, also fares better among the highereducated in highly urbanized areas. The main difference between their electorates is the relatively flat income profile of GreenLeft voters and, interestingly, their self-identification with the "upper-middle" class (but not the "upper" class). Finally, the anti-immigration PVV is closer to the Social Democrats and the Socialists than to any other parties in socioeconomic terms: it is disproportionately supported by low-income, lower-educated, working-class voters, even if the overrepresentation of the lower educated is strongest among the PVV's electorate. What appears to distinguish these two groups most, however, is their support among religious minorities. In the past decade, nearly half of all Muslim voters voted for the Social Democrats, while not a single one declared having supported the PVV in the postelectoral surveys used in this section. A new nativist cleavage, in addition to the sociocultural 
and environmental issues embodied by the GreenLeft and D66, therefore seems to have contributed to the blurring of traditional class and religious cleavages in the Netherlands in recent years.

\section{Switzerland}

\section{The Emergence of the Swiss Political System}

The modern Swiss state was born in 1848 , at the end of a brief and almost bloodless civil war that opposed the minority Catholic cantons to their Protestant counterparts. For centuries, Switzerland had existed as a rather loose confederacy of allied states and subject territories, whose primary function was to protect its members' independence from foreign powers. Following the Reformation, only some of the cantons converted to Protestantism, thus generating a long-lasting divide within the Confederacy that would lead to several internal conflicts and hamper any attempts to establish a more centralized state.

It was not until Napoleon's invasion in 1798, and the subsequent creation of the Helvetic Republic that Switzerland was first unified under a central government. The wildly unpopular Republic lasted less than five years, but it prompted the emergence of the two political movements that would shape Swiss politics throughout the $19^{\text {th }}$ century. On the one hand, the Radicals (liberals) supported a tighter union between the cantons, the protection of individual rights, and the separation of church and state. On the other hand, the Catholic Conservatives set to defend cantonal autonomy and the overall status-quo. The two movements would later transform into political parties at the turn of the twentieth century, with the creation of the Free Democratic Party in 1894 and the Christian Democratic Party in 1912.

In the decades that followed the fall of Napoleon, the Radicals rapidly gained support across the Protestant cantons - particularly among the bourgeoisie and in the countryside - which saw in a democratic federal state the means to contain the power of traditional urban elites. The swift rise of the Radicals spurred fear among the Catholic minority who formed a parallel 
alliance, the Sonderbund, ultimately leading to the outbreak of the 1847 civil war. The Catholics were defeated within a few weeks and, shortly after, a new constitution was adopted, transforming Switzerland into a federal state.

The 1848 Constitution laid the foundations of modern Swiss democracy. Largely based on the United States Constitution, it preserved significant cantonal autonomy and established a bicameral parliament, the Federal Assembly, composed of a chamber representing the people (the Nacional Council), and one representing the cantons (the Council of States). Both chambers were elected by universal male suffrage. Women, however, would have to wait until 1971 to be allowed to vote in federal elections, making Switzerland the last Western democracy and one of the last countries on earth to fully expand voting rights. The executive power was given to the Federal Council, a council of seven members elected by the parliament and ruling in collegiality. The Constitution also introduced direct democracy at the federal level in the form of a mandatory referendum for all constitutional amendments, which, to this day, have to be approved by a majority of both the population and the cantons. The practice of direct democracy was then further expanded in 1874 and 1891, with the introduction of the optional legislative referendum and the popular initiative respectively, becoming "perhaps the most crucial institution of the Swiss political system" (Kriesi and Trechsel 2008). As a consequence of the large degree of decentralization and the practice of direct democracy, the power of the federal state has remained significantly limited to this day.

In addition to the religious divisions, Switzerland was also shaped by a long-lasting cleavage opposing the cities to the countryside. Multiple rural revolts erupted against the urban elites already during the times of the Confederacy. As support for the liberals slowly started to fade among the popular classes in the second half of the $19^{\text {th }}$ century, two new political forces emerged. In the cities, the labor movement gained strength, and the Swiss Social Democratic Party was founded in 1888. In the countryside, farmers' parties grew, although they would not unite in a federal party, the Party of Farmers, Traders and Independents, until 1936. 
Until the rise of green parties during the last two decades, these four political forces dominated Switzerland's political arena (Figure 7). After World War I, the Free Democratic Party lost its uncontested majority and in the late 1920s, the Social Democrats became the biggest party in parliament. For almost fifty years, vote shares remained quite stable albeit also quite split, with no party gathering more than 30 percent of the vote. This made of Switzerland's one of the most fragmented electoral systems among Western democracies, but also one of the least volatile. In 1959, stability was brought as well into the Federal Council, with the adoption of the "Magic Formula". The seven seats were allocated according to a fixed yet unwritten rule which gave two seats each to the Social Democrats, the Free Democratic Party, and the Christian Democrats, and one to the Farmers' Party. This uncommon permanent grand coalition of left- and right-wing parties made of Switzerland the paradigmatic example of a consensual democracy (Kriesi and Trechsel 2008).

Consensual politics, however, together with the high degree of decentralization and the use of direct democracy have arguably contributed to discourage electoral participation in federal elections, which reached an alarmingly low $45 \%$ in 2019 , after declining steadily for over a century.

\section{The Rise of the Swiss People's Party and the Polarization of Swiss Politics}

In the late 1960s, the Western world saw the rise of a new ideological conflict, opposing what have been called "libertarian-universalistic" and "traditionalist-communitarian" poles (Oesh and Rennwald 2010). The Social Democrats were particularly quick in adopting the universalistic ideas of the New Left, which included the defense of equal rights for women and sexual minorities, and the protection of the environment. Simultaneously, local environmentalist parties started appearing across Switzerland, and the Green Party was finally founded at the federal level in 1983. The Swiss left progressively concentrated around these two parties, constituting "an exceptionally strong universalistic pole" (Kriesi 2015). The traditionalist pole, however, was not yet represented in the political system. 
In 1971, the old Farmers' Party became the Swiss People's Party after merging with a small centrist party. The fourth force in the Swiss parliament and the Federal Council, it played a secondary role in the country's politics at first. After the rise of Christoph Blocher to the head of the Zurich branch in 1977, however, the party experienced a deep structural and ideological transformation. Described by former Trump campaign advisor and far-right ideologue Steve Bannon as "Trump before Trump" (Karnitschnig 2018), it is difficult to overstate the role played by Blocher in the transformation of Swiss politics. A successful industrialist and a fierce opponent of Swiss integration into the international community, Blocher transformed the Swiss People's Party from a moderate, centrist organization of farmers and small business owners into a radical, anti-immigration, anti-European party with a fiercely liberal economic agenda. The new Swiss People's Party came to represent the rejection of the universalist ideas adopted by the New Left, already latent in large sectors of Swiss society (Bornschier 2015). The ideological shift and the aggressive campaigning strategies introduced by Blocher proved very effective, propelling the party from a modest 15 percent of the vote in 1995 to a staggering 29 percent in 2007, and turning it into one of the most successful far-right parties in Western Europe (Bornshier 2015).

The arrival of the New Left and the rise of Blocher's Swiss People's Party led to a significant polarization of Swiss politics. The long-lasting stability of the Swiss political system ultimately came to an end in the 1990s, with the exponential rise of the Swiss People's Party and the rapid decline of traditional centre-right parties. In 2003, the Magic Formula was broken for the first time since 1959, as the Swiss People's Party, which had become the biggest party in parliament, took a second seat in the Federal Council at the expense of the Christian Democrats (Kriesi, Lachat, Selb, Bornschier, and Helbling, 2005). 
How did the dramatic transformation of the Swiss party system affect electoral choices? Using existing post-electoral surveys, we are able to track changes in the composition of the electorate of Swiss political parties in federal elections between 1967 and $2015 .^{6}$

As in many Western democracies, the last fifty years have been marked by the reversal of the educational cleavage. Figure 8 shows the support for the Social Democrats, the Green Party, the Green Liberals, the Alliance of Independents, and other small centrist and left-leaning parties among highest-educated and top-income voters since 1967. This group of parties, while heterogeneous, shares similar views on immigration, European integration, and environmental protection issues, which stand at the center of the political debate in Switzerland (Bornshier 2015). Support among the highest-educated voters for these parties has dramatically shifted over the past decades. While in the late 1960s and early 1970s, highest-educated voters were slightly less likely to vote for these parties than the rest of the electorate, by the 2010 s they had become more likely to do so by over 15 percentage points, after controlling for other socioeconomic factors.

This major shift is not only explained by the rise of new parties, but also by a reversal in the electorate of the traditional left. Indeed, the Social Democrats have attracted a larger share of university graduates than primary-educated voters since the 1990s, coinciding with the rise of the Swiss People's Party. ${ }^{7}$ The reversal is also clear when looking at voting by occupation. The Social Democrats and Communists lost the support of clerks and manual workers in the 1990s, as the Swiss People's Party became the new party of the working class. ${ }^{8}$ Social and cultural specialists, a broad category including workers involved in "medical services, teaching, social work, arts and journalism" (Kriesi 1989) among others, have become the new

\footnotetext{
${ }^{6}$ See appendix Table CA1 for data sources.

${ }^{7}$ See appendix Figures CD1 to CD38 for detailed results by party.

${ }^{8}$ See appendix Figure CB14. See also Rennwald (2014).
} 
stronghold of the left across many Western Democracies, but the phenomenon is particularly strong in Switzerland. This development is consistent with the idea of the primacy of cultural and identity issues over economic concerns in Swiss politics. In this regard, Rennwald and Evans (2014), show that, despite finding itself further to the left in economic issues and sharing similar cultural values, the Swiss Social Democrats lost the support of the working class, while the Austrian SPÖ did not, or at least not to the same extent (see below). Behind this, they state, is the fact that the Swiss Social Democrats have given a more weight to cultural issues in their public discourse, a choice potentially motivated by the historical weakness of class voting in Switzerland, as religious and language divides hindered the mobilization of a united working class (Lijphart 1979). As a result of these shifts, Switzerland now shows one of the strongest educational cleavages among Western democracies (Gethin, Martínez-Toledano, and Piketty forthcoming).

The importance of the cultural dimension of politics can also be seen in the exceptional weakness of income in accounting for divisions between left and right (Figure 8). Income only matters when it comes to the division between the moderate and the radical right, and the overall party choice within the moderate right bloc. The center-right Free Democratic Party remains the party of the elite, attracting both top-income and higher-educated voters, despite now competing for the latter with the left. Both the moderate Christian Democrats and the farright Swiss People's Party fare better among low-income, lower-educated voters, but in the case of the Swiss People's Party, the cleavage is much stronger (see Table 3). In 2011-2015, they gathered $33 \%$ of primary educated voters, but only $10 \%$ of university graduates.

Beyond educational and income cleavages, the historical rural-urban divide remains very significant in Switzerland. Despite changes in its political platform, the Swiss People's Party - heir of the Farmer's Party - still fares significantly better in rural areas. Conversely, both the Social Democrats and the two green parties gather much of their support from urban voters. ${ }^{9}$ Given the growth of the center-left bloc in recent elections, and the strong territorial

\footnotetext{
${ }^{9}$ See appendix Figures CB7 and CC14.
} 
bias of the Swiss People's Party's electorate, the rural-urban cleavage will likely remain a key feature of Swiss politics and may even gain more weight in the near future.

On the contrary, the religious cleavage, which played such a central role in the formation of the Swiss political system, seems to be fading away. This has been mostly to the detriment of the Christian Democrats, as they never succeeded in expanding their electorate beyond their traditional Catholic voting base, now eroding.

In contrast to the Belgian experience, language divisions have played a rather small role in Swiss federal elections, which speaks perhaps to the successful construction of Swiss national identity as a "unity in diversity" (Kriesi and Trechsel 2008). The Swiss People's Party, historically tied to German-speaking Switzerland, is the only party that has consistently concentrated most of its electorate in a given linguistic region. However, after peaking in the 1990s, the language gap has reduced significantly, as support for the party grew in the Frenchand Italian-speaking regions. ${ }^{10}$ Language divisions have, nevertheless, been quite strong in referendums concerning Swiss relations with the EU, as Italian and German-speakers have shown much stronger opposition to further integration (Kriesi and Trechsel 2008).

Overall, the emergence of a new cultural divide and the subsequent polarization of Swiss politics have led to the emergence of a multi-elite party system, where the Social Democrats and the green parties are increasingly supported by higher-educated voters in urban areas, while the far-right Swiss People's Party concentrates the rural, lower-educated, and lowincome vote. The electorates of the historical center-right parties, the Free Democratic Party and the Christian Democrats, have not changed much in composition, albeit experiencing a significant decline in size. The Free Democratic Party remains the party of top income, highly educated voters, and the Christian Democrats are still, above all, a Catholic party. The two parties stand thus as vestiges of a seemingly bygone era of political stability, once the essence of Swiss democracy.

\footnotetext{
${ }^{10}$ See appendix Figure CD35.
} 


\section{Austria}

The Transformation of the Austrian Party System

Austria took a first step towards democracy in 1873, when a meager 6 percent of the adult male population elected for the first time the Imperial Assembly of Cisleithania, but it was only by 1919 that the enfranchisement of women paved the way to universal suffrage. Two main political forces had materialized during the second half of the nineteenth century. On the left were the Social Democrats, who appealed to class struggle, the nationalization of big corporations, and the taxation of elites. On the right were the Christian Socialists, supported by the Catholic Church and appealing to farmers, artisans, and the bourgeoisie. German Nationalists consisted a third movement, and received nearly 6 percent of the votes in the 1919 elections. The dominant themes of their campaigns were the unification of Austria and Germany (Anschluss), anticlericalism, and antisemitism. The majority of their members would join Hitler's Nazi Party after the German annexation of Austria in 1938 (Rathkolb 2008).

The organizations that emerged in the Second Republic were the direct continuation of prewar political movements. The Austrian People's Party (Österreichische Volkspartei, ÖVP), created in 1945, replaced the Christian Social party dissolved in 1934 and secured a majority of votes and seats in the 1945 election (see Figure 9). Given the task of reconstruction and the memory of the war, the ÖVP still formed a coalition with the Socialist Party (Sozialistische Partei Österreichs, SPÖ) and included a communist minister in the cabinet. This was part of a historical tradition of consensual democracy, originated in the First Republic (1919-1934), which aimed at buffering the antagonistic "pillars" of Austrian society by incorporating members of all major parties in the cabinet (Rathkolb 2008). It took full shape after 1945 under the proporz system of proportional allocation of posts by party in the public sector and in the administration (Luther 1989). Coalition governments hence became the norm in Austria, leading to alliances that would appear politically infeasible in other Western countries. Among the most surprising of these was the coalition concluded between the 
Greens and Sebastian Kurz's ÖVP in January 2020 in spite of their diametrically opposite views on immigration policy (Janik 2020).

Austria's party system was particularly stable from 1945 to the mid-1980s. After a period of alternation between the ÖVP and the SPÖ, the SPÖ became the dominant party between 1970 and 1983. The Federation of Independents (Verband der Unabhängigen, VdU), rebranded as Freedom Party of Austria (Freiheitliche Partei Österreichs, FPÖ) in 1956, represented the remnants of German nationalism, but it shifted to office-seeking strategies from the late 1960s. Under Norbert Steger (1980-1986), in particular, the FPÖ attempted to remold itself into a centrist liberal party promoting anti-statism and free markets (Luther 2008). The Communist Party, already weak in 1945, lost significance in the 1950s and 1960s.

In 1986, Jörg Haider took over the leadership of the FPÖ and transformed it into a radical anti-establishment party. Key to its growing success were its opposition to the proporz system and coalition governments (accused of being undemocratic and corrupted), immigration, crime, and EU skepticism. This strategy yielded its benefits in 1999, when the FPÖ narrowly overtook the ÖVP and became the second biggest party in Austria for the first time in its history. Importantly, the FPÖ was able to capture constituencies from both the ÖVP and the SPÖ with a program mixing elements from the right and the left, including anti-immigration policies, market liberalization, and social policies appealing to blue-collar workers. Internal conflicts and dissatisfaction with the coalition ÖVP-FPÖ government created after the 1999 elections nonetheless led to the collapse of the FPÖ in the 2002 election, followed by the creation of the splinter Alliance for the Future of Austria (Bündnis Zukunft Österreich, BZÖ) by Haider in 2005 (Aichholder, Kritzinger, Wagner, and Zeglovits 2014). The party however gained back its success in the elections of 2008, 2013, and 2017, emphasizing the need for stricter immigration controls (Plescia, Kritzinger, and Oberluggauer 2018). In 2019, support for the FPÖ plummeted again, in the context of the Ibiza affair, which involved a discussion between vice-Chancellor Heinz-Christian Strache and a woman posing as a niece of a Russian oligarch over an exchange of news coverage against government contracts. 
The decline of traditional parties has also coincided with the rise of the Greens and the Liberals (Figure 9). The Green Alternative (Die Grünen - Die Grüne Alternative since 1993) has grown significantly since the mid-1980s, from less than 5 percent of votes to 14 percent in the 2019 elections. At the center of the political spectrum, the Liberal Forum, founded in 1993 by liberal members of the FPÖ, was successful in the mid-1990s, promoting liberalism and free-market policies, but quickly lost support. It merged in 2014 with the NEOS to create the NEOS - The New Austria and Liberal Forum, which has been growing since then and reached 8 percent of votes in 2019 .

The existing literature on political cleavages in Austria has revealed long-run trends comparable to that visible in other Western democracies. In the 1950s and 1960s, three main cleavages divided the Austrian electorate: a religious cleavage between Catholics and nonbelievers, a welfare state cleavage opposing white collars and blue collars, and a cleavage between citizens with Austrian and German identities. The existence of distinct political cultures underlying party support, or Lager (camps), then ensured a stable basis of support for the three main parties (Luther and Müller 1992). The SPÖ and the ÖVP represented the first two cleavages, while the national cleavage, at first represented by the FPÖ, disappeared as German identities dwindled and new voters replaced the prewar generations. This cleavage structure underwent further changes in the past decades, including the decline of party identification, the growth of "late deciders", the decrease of electoral turnout, and the near disappearance of class voting (Plasser and Ulram 2008). These changes happened later in Austria than in most Western democracies, but at a faster pace: they mainly took place in the 1980s and 1990s, which points to the role of the FPÖ in destabilizing traditional partisan affiliations (Plasser and Seeber 2008).

\section{The Emergence of a Multi-Elite Party System in Austria}

How has the transformation of Austria's party system shaped the reversal of the educational cleavage and the emergence of a multi-elite party system? Figure 10 shows the relative support for the SPÖ, the KPÖ, the Greens, the Liberal Forum, and NEOS among highest- 
educated and top-income voters since 1971. Highest-educated voters were less likely to vote for the left by 15 percentage points in 1971; in the last two elections, they had become more likely to do so by 15 points. Top-income voters have also converged in their voting patterns, but continue to support the right. Austria has therefore clearly transitioned to a multi-elite party system.

Three parallel dynamics drove these changes. First, the FPÖ grew, and its voting base went through a radical transformation: while in 1971, it was more successful among highesteducated and top-income voters, it gradually became the party of low-income, lower-educated voters. This is consistent with the three phases of FPÖ ideology, from a centrist liberal party in the 1970 s to a catchall anti-establishment party in the 1980 s, and finally to an antiimmigration radical right party. Secondly, the rise of the Greens and NEOS, both disproportionately supported by university graduates in urban areas, reinforced the reversal of the educational cleavage. Thirdly, the SPÖ's electorate has also become more diverse, first in terms of income in the 1970s and 1980s, and then in terms of education in the most recent elections. ${ }^{11}$

Table 4 provides a synthetic picture of the structure of political cleavages in Austria in the past decade. Both the SPÖ and the FPÖ appear to be stronger among primary-educated and low-income voters, but university graduates are more strongly biased against the FPÖ. The SPÖ's lower emphasis on new liberal cultural issues could explain why it still makes better scores among the lower educated, especially in comparison to Switzerland, where we have seen that historical left-wing parties are now disproportionately supported by the higher educated (Rennwald and Evans 2014). Rural-urban locations distinguish left from right more clearly: the SPÖ, the KPÖ, the Greens and the NEOS are all stronger in cities. Religion also clearly distinguishes the left from the right: more than 85 percent of Muslims (about 1.5 percent of the electorate in 2017), and 60 percent of non-believers (20 percent of the electorate), voted for socialist and liberal parties in 2013-2017.

\footnotetext{
${ }^{11}$ See appendix Figures DD1 to DD20.
} 


\section{References}

K. Aarts and J. Thomassen, "Dutch Voters and the Changing Party Space 1989-2006," Acta Politica 43, no. 2-3 (2008): 203-234.

J. Aichholder, S. Kritzinger, M. Wagner, and E. Zeglovits, "How has Radical Right Support Transformed Established Political Conflicts? The Case of Austria," West European Politics 37, no. 1 (2014): 113-137.

R. B. Andeweg and G. A. Irwin, Governance and Politics of the Netherlands (Palgrave Macmillan, 2005), Chapters 1 and 2.

L. Bauluz, A. Gethin, C. Martínez-Toledano, and M. Morgan, "Historical Political Cleavages and Post-Crisis Transformations in Italy, Spain, Portugal and Ireland, 1953-2020" (WID.world Working Paper, 2021).

J. Beaufays, "Belgium: A Dualist Political System?," Publius: The Journal of Federalism 18, no. 2 (1988): 63-73.

S. Bornschier, "The New Cultural Divide and the Two-Dimensional Political Space in Western Europe," West European Politics 33, no. 3 (2010): 419-444.

S. Bornschier, "The New Cultural Conflict, Polarization, and Representation in the Swiss Party System, 1975-2011,” Swiss Political Science Review 21, no. 4 (2015): 680-701.

L. de Jonge, "The Curious Case of Belgium: Why is There no Right-Wing Populism in Wallonia?," Government and Opposition (2020): 1-17. 
K. Deprez and L. Vos, Nationalism in Belgium: Shifting Identities, 1780-1995 (Springer, 2016).

K. Deschouwer, "And the Peace Goes on? Consociational Democracy and Belgian Politics in the Twenty-First Century," West European Politics 29, no. 5 (2006): 895-911.

K. Deschouwer, The Politics of Belgium (Palgrave Macmillan, 2012).

A. Gethin, "Political Cleavages, Class Structures, and the Politics of Old and New Minorities in Australia, Canada, and New Zealand, 1963-2019” (WID.world Working Paper, 2021).

A. Gethin, C. Martínez-Toledano, and T. Piketty, Political Cleavages and Social Inequalities. A Study of Fifty Democracies, 1948-2020 (Harvard University Press, forthcoming).

F. Kosse and T. Piketty, "Electoral Cleavages and Socioeconomic Inequality in Germany 1949-2017” (WID.world Working Paper, 2020).

H. Kriesi, "New Social Movements and the New Class in the Netherlands," American Journal of Sociology 94, no. 5 (1989): 1078-1116.

H. Kriesi, "Restructuration of Partisan Politics and the Emergence of a New Cleavage Based on Values," West European Politics 33, no. 3 (2010): 673-685.

H. Kriesi, "Conclusion: The Political Consequences of the Polarization of Swiss Politics," Swiss Political Science Review 21, no. 4 (2015): 725.

H. Kriesi and A. H. Trechsel, The Politics of Switzerland: Continuity and Change in a Consensus Democracy, (Cambridge University Press, 2008). 
H. Kriesi, R. Lachat, P. Selb, S. Bornschier, and M. Helbling, Der Aufstieg der SVP. Acht Kantone im Vergleich, (Verlag Neue Zürcher Zeitung, 2005).

A. Lijphart, The Politics of Accommodation: Pluralism and Democracy in the Netherlands (University of California Press, 1975).

A. Lijphart, "Religious vs. Linguistic vs. Class Voting: The "Crucial Experiment" of Comparing Belgium, Canada, South Africa, and Switzerland." The American Political Science Review 73, no. 2 (1979): 442-58.

A. Lijphart, "From the Politics of Accommodation to Adversarial Politics in the Netherlands: A Reassessment," West European Politics 12, no. 1 (1989): 139-153.

K. R. Luther, "Dimensions of Party System Change: The Case of Austria," West European Politics 12, no. 4 (1989): 3-27.

K. R. Luther, "Electoral Strategies and Performance of Austrian Right-Wing Populism, 19862006," in The Changing Austrian Voter, Chapter 5.

K. R. Luther and W. C. Müller, "Consociationalism and the Austrian Political System," West European Politics 15, no. 1 (1992): 1-15.

D. Oesch and L. Rennwald, "The Class Basis of Switzerland's Cleavage between the New Left and the Populist Right," Swiss Political Science Review 16, no. 3 (2010): 343-371.

B. O'Leary, "Consociation in the Present," Swiss Political Science Review 25, no. 4 (2020): $556-574$.

C. Plescia, S. Kritzinger, and P. Oberluggauer, "Austria 2017: Conflict Mobilization in a Reconstructing Political Landscape," in The Year of Challengers? Issues, Public Opinion, and 
Elections in Western Europe in 2017, ed. L. De Sio and A. Paparo (Centro Italiano Studi Elettorali, 2018), 189-191.

F. Plasser and G. Seeber, "Austrian Electoral Behavior in International Comparison," in The Changing Austrian Voter, Chapter 7.

T. Piketty, "Brahmin Left vs Merchant Right: Rising Inequality and the Changing Structure of Political Conflict. (Evidence from France, Britain and the US, 1948-2017)" (WID.world Working Paper 2018/7, 2018).

F. Plasser and P. A. Ulram, "Electoral Change in Austria," in The Changing Austrian Voter, Chapter 2.

O. Rathkolb, "The Austrian Voter in Historical Perspective," in The Changing Austrian Voter, ed. G. Bischof and F. Plasser (Transaction Publishers, 2008), Chapter 1.

L. Rennwald, "Class (Non)Voting in Switzerland 1971-2011: Ruptures and Continuities in a Changing Political Landscape,” Swiss Political Science Review 20, no. 4 (2014): 550-572.

L. Rennwald and G. Evans, "When Supply Creates Demand: Social Democratic Party Strategies and the Evolution of Class Voting," West European Politics 37, no. 5 (2014): $1108-1135$.

N. Rink, K. Phalet, and M. Swyngedouw, "The Effects of Immigrant Population Size, Unemployment, and Individual Characteristics on Voting for the Vlaams Blok in Flanders 1991-1999," European sociological review 25, no. 4 (2009): 411-424.

J. J. M. Van Holsteyn, "The Radical Right in Belgium and the Netherlands," in The Oxford Handbook of the Radical Right, ed. J. Rydgren (Oxford University Press, 2018), Chapter 24. 
K. Vossen, The Power of Populism: Geert Wilders and the Party for Freedom in the Netherlands (Routledge, 2016): 1.

L. D. Winter and P. Dumont, "Belgium: Party System(S) on the Eve of Disintegration?," in Changing Party Systems in Western Europe, ed. D. Broughton and M. Donovan (Pinter, 1999): 183-206.

E. Witte, J. Craeybeckx, and A. Meynen, Political History of Belgium: From 1830 onwards (Asp/Vubpress/Upa, 2009).

M. Karnitschnig, "Steve Bannon Populist Roadshow Hits Europe", Politico, March 6 2018, accessed August 12 2020, https://www.politico.eu/article/steve-bannon-populism-donaldtrump-i-still-love-the-guy/. 
Figure 1 - Election results in Belgium, 1946-2019

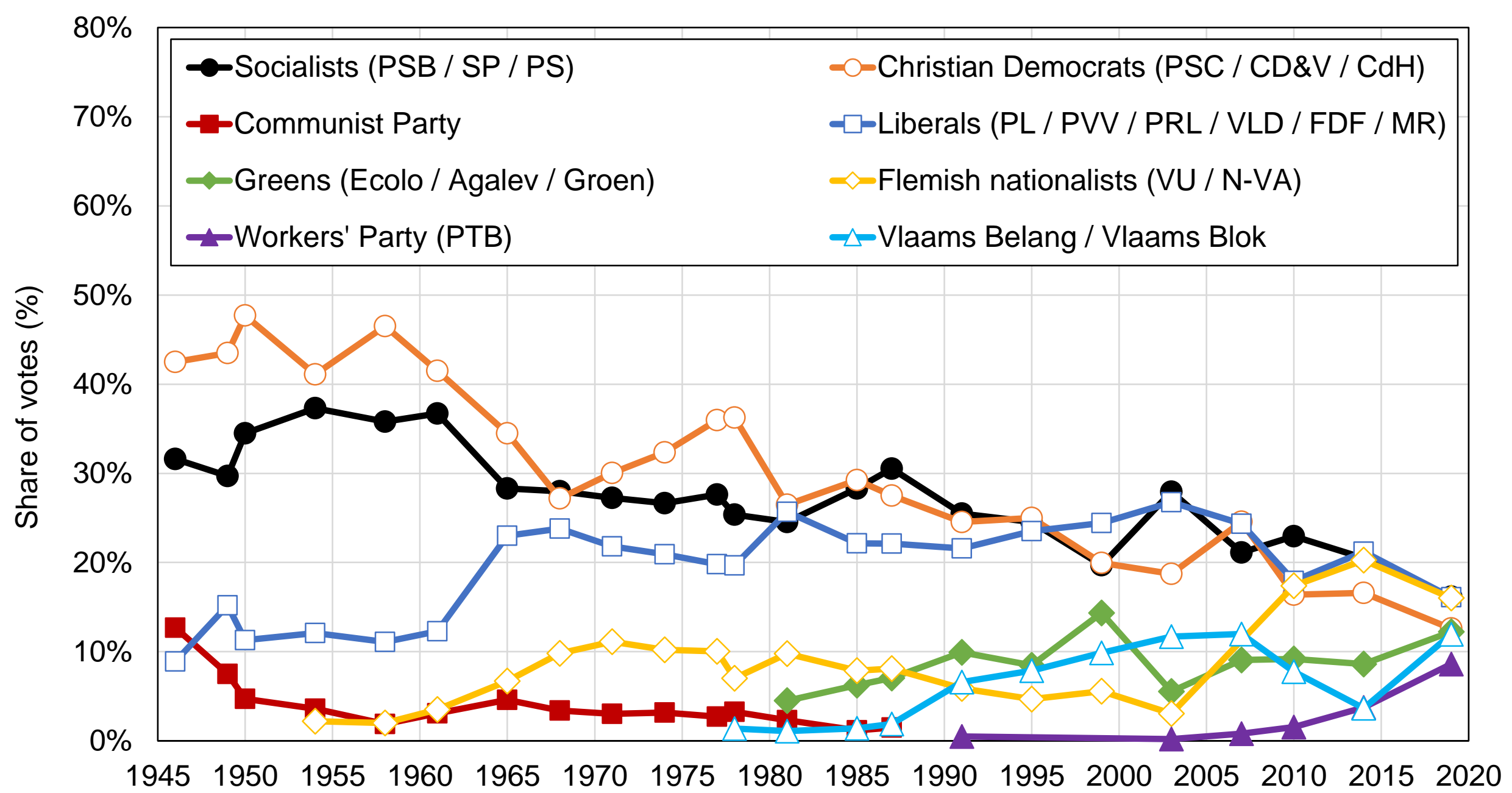

Source: authors' computations using official election

Note: the figure shows the share of votes received by selected political parties or groups of parties in federal elections held in Belgium between 1946 and 2019. Flemish nationalists received 16\% of votes in 2019. 
Figure 2 - Towards a multi-elite party system in Belgium, 1971-2014

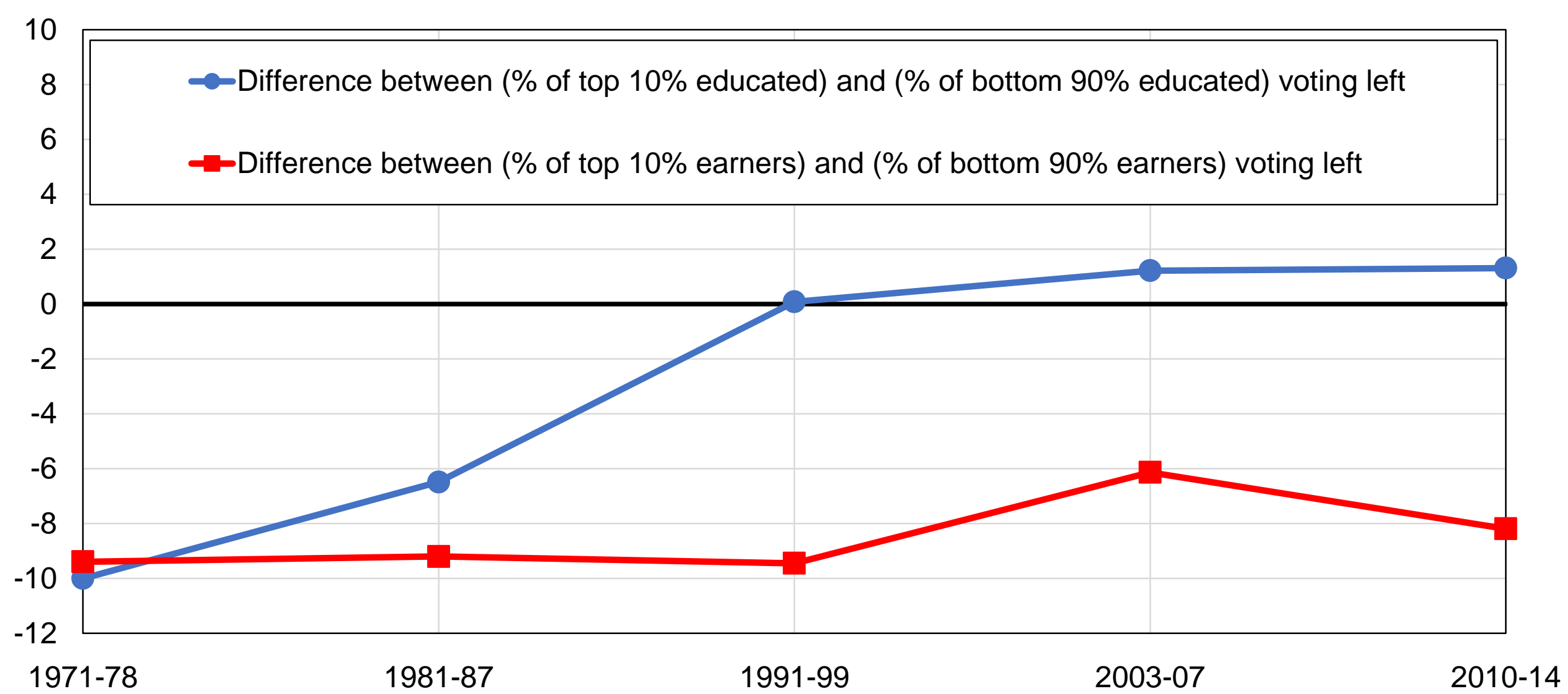

Source: authors' computations using Belgian political attitudes surveys.

Note: the figure shows the relative support of highest-educated and top-income voters for left-wing parties (PS / SP / Ecolo / Agalev / PTB). In the 1970s, highest-educated and top-income voters were less likely to vote for left-wing parties than low-income and lowereducated voters. The left-wing vote has become increasingly associated with higher-educated voters, leading Belgium to come closer to becoming a "multi-elite party system". Estimates control for income/education, age, gender, employment status, marital status, religion, church attendance, region, and language. 
Figure 3 - The regional cleavage in Belgium, 1971-2014

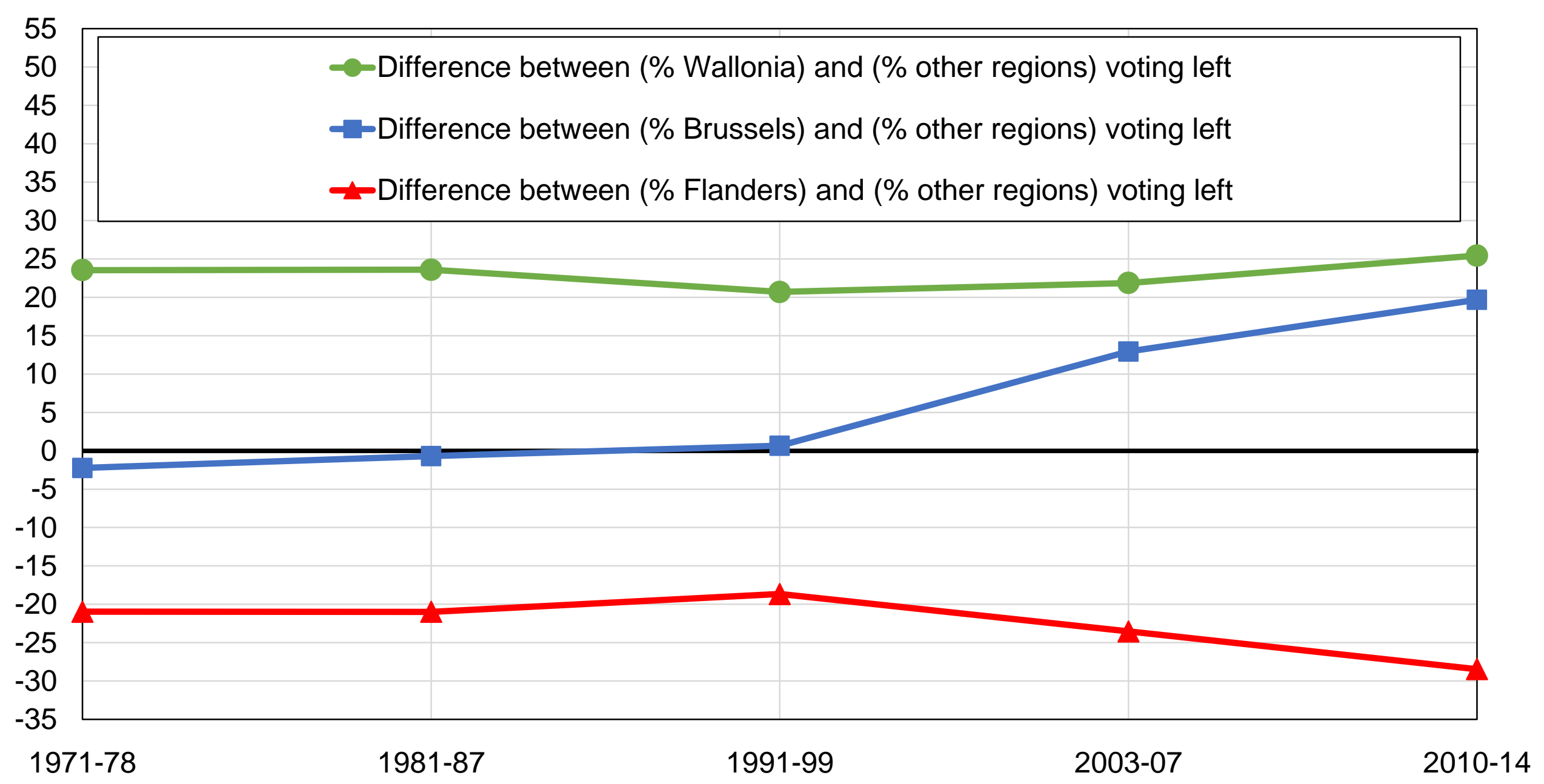

Source: authors' computations using Belgian political attitudes surveys.

Note: the figure shows the relative support of the main Belgian regions for left-wing parties (PS / SP / Ecolo / Agalev / PTB), after controlling for income, education, age, gender, employment status, marital status, religion, and church attendance. Wallonia has remained significantly more likely to vote for left-wing parties than Flanders throughout the past decades, while Brussels has become increasingly supportive of left-wing parties. 


\begin{tabular}{|c|c|c|c|c|c|c|}
\hline \multicolumn{7}{|c|}{ Table 1 - The structure of political cleavages in Belgium, 2011-2014 } \\
\hline \multirow[b]{3}{*}{ Education } & \multicolumn{6}{|c|}{ Share of votes received (\%) } \\
\hline & $\begin{array}{c}\text { PS / SP / } \\
\text { PTB }\end{array}$ & $\begin{array}{l}\text { Ecolo / } \\
\text { Groen }\end{array}$ & VLD / MR & $\begin{array}{c}\text { CD\&V / } \\
\text { CdH }\end{array}$ & $\mathrm{N}-\mathrm{VA}$ & $\begin{array}{l}\text { Vlaams } \\
\text { Belang }\end{array}$ \\
\hline & \\
\hline & $34 \%$ & $3 \%$ & $14 \%$ & $20 \%$ & $20 \%$ & $4 \%$ \\
\hline Secondary & $27 \%$ & $6 \%$ & $18 \%$ & $20 \%$ & $20 \%$ & $4 \%$ \\
\hline \multicolumn{6}{|l|}{ Income } & $1 \%$ \\
\hline Bottom $50 \%$ & $30 \%$ & $7 \%$ & $17 \%$ & $22 \%$ & $16 \%$ & $3 \%$ \\
\hline Middle $40 \%$ & $22 \%$ & $11 \%$ & $21 \%$ & $18 \%$ & $21 \%$ & $3 \%$ \\
\hline Top 10\% & $13 \%$ & $11 \%$ & $28 \%$ & $17 \%$ & $26 \%$ & $2 \%$ \\
\hline \multicolumn{7}{|l|}{ Religion } \\
\hline No religion & $25 \%$ & $12 \%$ & $20 \%$ & $12 \%$ & $22 \%$ & $4 \%$ \\
\hline Catholic & $17 \%$ & $5 \%$ & $21 \%$ & $34 \%$ & $17 \%$ & $2 \%$ \\
\hline Protestant & $30 \%$ & $9 \%$ & $12 \%$ & $24 \%$ & $18 \%$ & $2 \%$ \\
\hline Muslim & $65 \%$ & $7 \%$ & $8 \%$ & $13 \%$ & $4 \%$ & $0 \%$ \\
\hline \multicolumn{7}{|l|}{ Region } \\
\hline Brussels & $35 \%$ & $16 \%$ & $26 \%$ & $13 \%$ & $2 \%$ & $1 \%$ \\
\hline Flanders & $15 \%$ & $8 \%$ & $15 \%$ & $24 \%$ & $31 \%$ & $5 \%$ \\
\hline Wallonia & $41 \%$ & $10 \%$ & $29 \%$ & $14 \%$ & $0 \%$ & $0 \%$ \\
\hline \multicolumn{7}{|l|}{ Language } \\
\hline Dutch & $12 \%$ & $10 \%$ & $15 \%$ & $27 \%$ & $32 \%$ & $4 \%$ \\
\hline French & $36 \%$ & $12 \%$ & $34 \%$ & $13 \%$ & $1 \%$ & $0 \%$ \\
\hline Other & $65 \%$ & $4 \%$ & $10 \%$ & $13 \%$ & $3 \%$ & $5 \%$ \\
\hline \multicolumn{7}{|c|}{$\begin{array}{l}\text { Source: authors' computations using Belgian political attitudes surveys. } \\
\text { Note: the table shows the average share of votes received by the main Belgian political parties } \\
\text { by selected individual characteristics during the } 2011 \text { and } 2014 \text { elections. The PS, SP, and } \\
\text { PTB received greater support from lower-educated voters, low-income voters, and Muslim } \\
\text { voters. Total vote shares correspond to those reported in surveys and may not match exactly } \\
\text { official election results. }\end{array}$} \\
\hline
\end{tabular}


Figure 4 - Election results in the Netherlands, 1946-2017

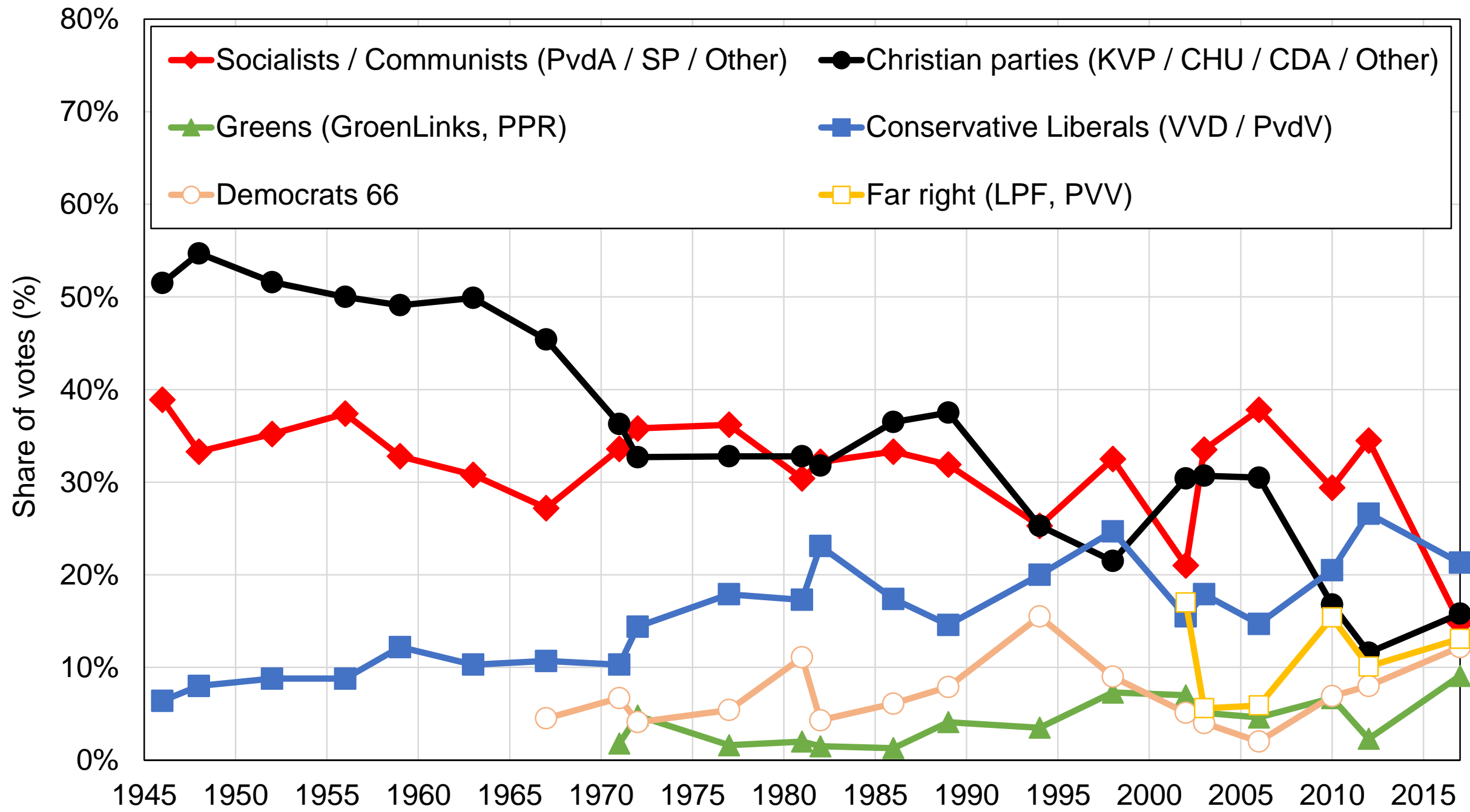

Source: authors' computations using official election results.

Note: the figure shows the share of votes received by selected political parties or groups of parties in general elections held in the Netherlands between 1946 and 2017. Conservative-liberal parties received $21 \%$ of votes in 2017 . 


\section{Figure 5 - The emergence of a multi-elite party system in the Netherlands, 1967-2017}

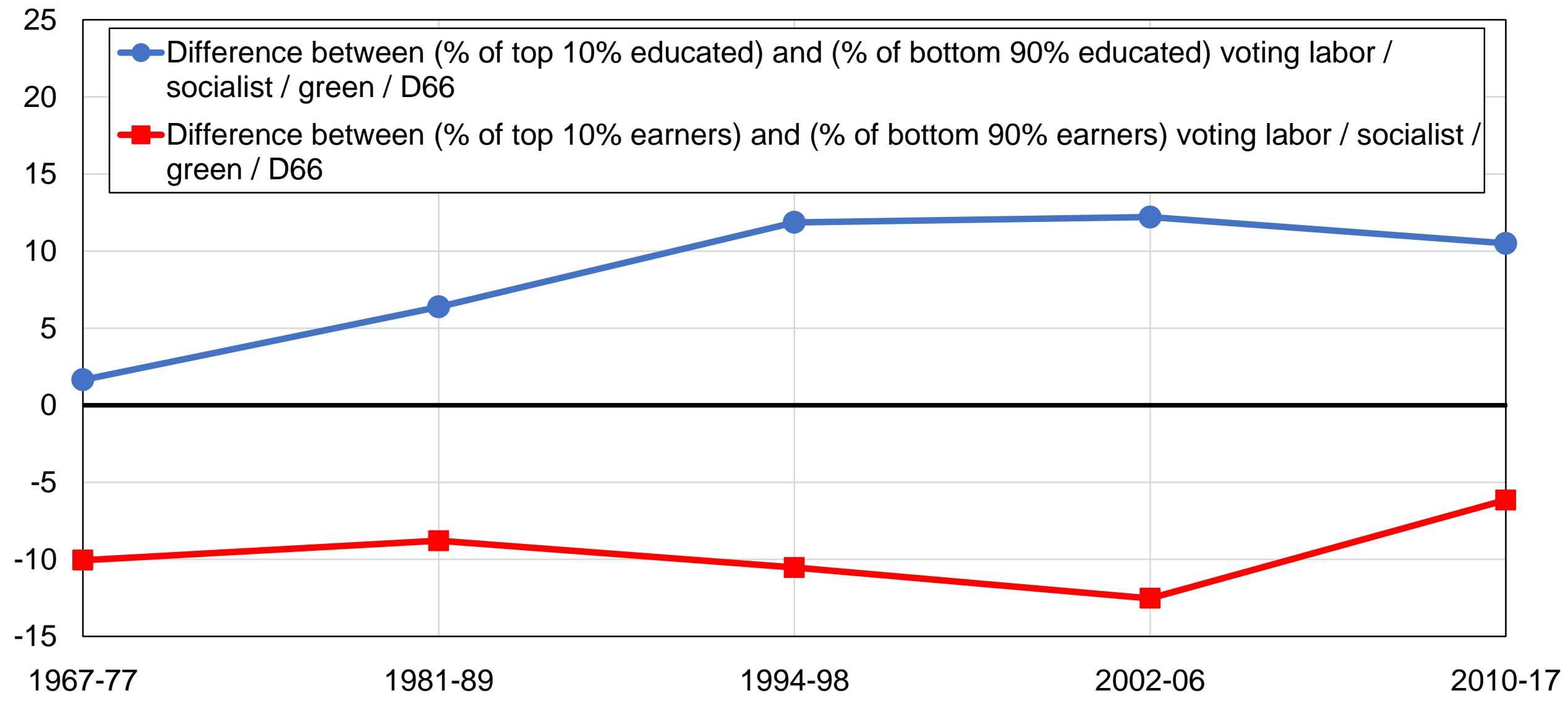

Source: authors' computations using Dutch electoral surveys.

Note: the figure shows the relative support of highest-educated and top-income voters for left-wing and liberal parties (PvdA / SP / GroenLinks / D66 / Other left). The left-wing / liberal vote has become increasingly associated with highest-educated voters, while topincome voters have remained more likely to vote for right-wing parties, giving rise to a "multi-elite party system". Estimates control for income/education, age, gender, employment status, marital status, religion, church attendance, region, location, union membership, and subjective social class. 


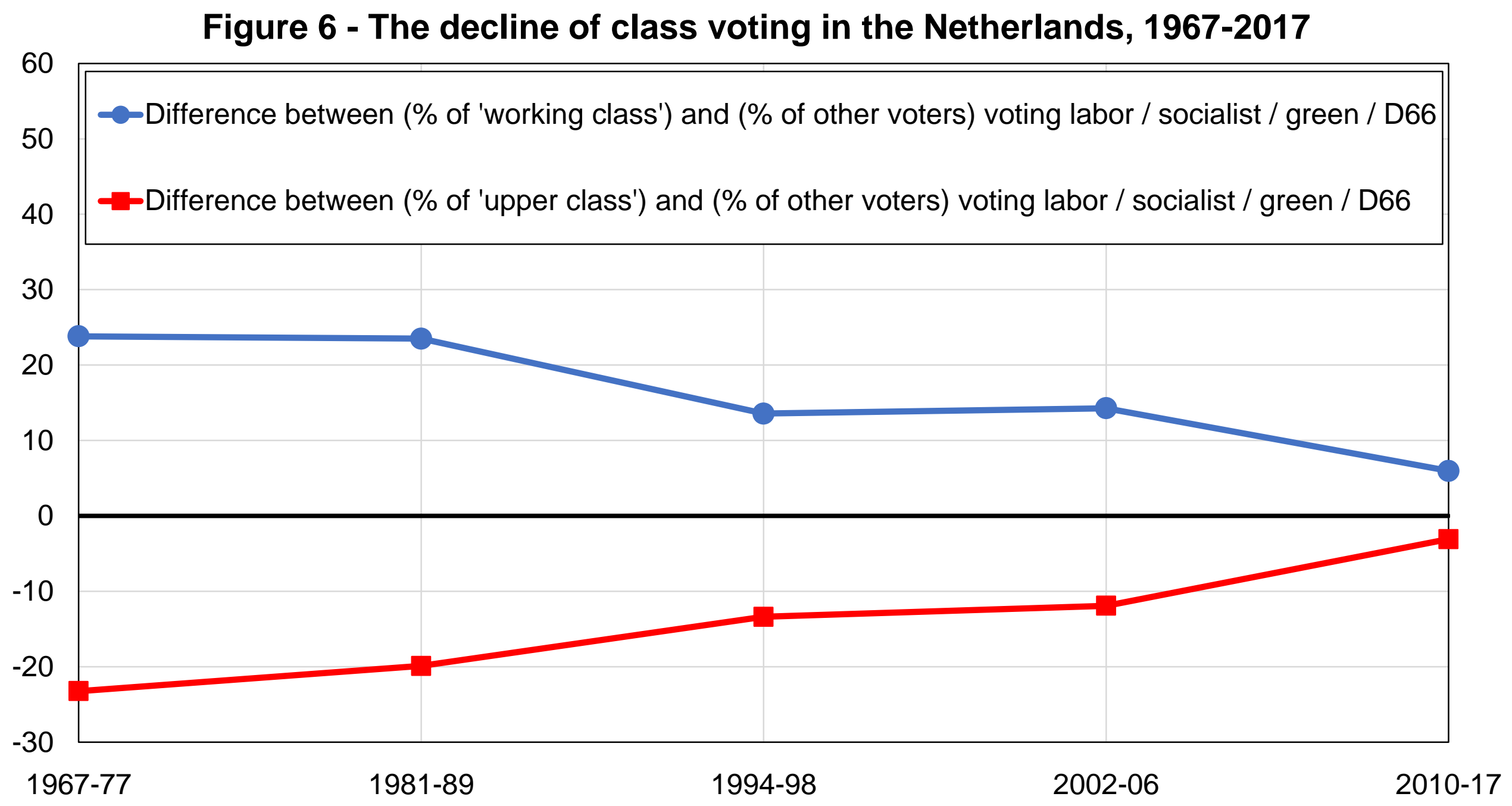

Source: authors' computations using Dutch electoral surveys.

Note: the figure shows the relative support of voters identifying with the "working class" and of voters identifying with the "upper class" for left-wing / liberal parties (PvdA / SP / GroenLinks / D66 / Other left). Class voting has declined significantly in the Netherlands in the past decades. Estimates control for income, education, age, gender, employment status, marital status, religion, church attendance, region, location, and union membership. 
Table 2 - The structure of political cleavages in the Netherlands, 2010-2017

\begin{tabular}{|c|c|c|c|c|c|c|c|}
\hline & & & hare of & otes re & ved $(\%$ & & \\
\hline & $\mathbf{S P}$ & PvdA & $\overline{G L}$ & D66 & CDA & VVD & PVV \\
\hline Education & & & & & & & \\
\hline Primary & $13 \%$ & $21 \%$ & $3 \%$ & $3 \%$ & $17 \%$ & $13 \%$ & $20 \%$ \\
\hline Secondary & $11 \%$ & $15 \%$ & $4 \%$ & $7 \%$ & $13 \%$ & $26 \%$ & $11 \%$ \\
\hline Tertiary & $5 \%$ & $16 \%$ & $10 \%$ & $17 \%$ & $9 \%$ & $28 \%$ & $3 \%$ \\
\hline Income & & & & & & & \\
\hline Bottom 50\% & $12 \%$ & $18 \%$ & $6 \%$ & $7 \%$ & $13 \%$ & $18 \%$ & $13 \%$ \\
\hline Middle $40 \%$ & $7 \%$ & $16 \%$ & $7 \%$ & $12 \%$ & $11 \%$ & $28 \%$ & $8 \%$ \\
\hline Top 10\% & $3 \%$ & $12 \%$ & $6 \%$ & $15 \%$ & $12 \%$ & $39 \%$ & $6 \%$ \\
\hline Social class & & & & & & & \\
\hline Working & $16 \%$ & $22 \%$ & $5 \%$ & $3 \%$ & $10 \%$ & $9 \%$ & $24 \%$ \\
\hline Upper working & $14 \%$ & $22 \%$ & $4 \%$ & $4 \%$ & $12 \%$ & $17 \%$ & $13 \%$ \\
\hline Middle & $9 \%$ & $15 \%$ & $6 \%$ & $10 \%$ & $14 \%$ & $25 \%$ & $9 \%$ \\
\hline Upper middle & $3 \%$ & $13 \%$ & $9 \%$ & $17 \%$ & $9 \%$ & $36 \%$ & $4 \%$ \\
\hline Upper & $3 \%$ & $9 \%$ & $4 \%$ & $23 \%$ & $8 \%$ & $45 \%$ & $2 \%$ \\
\hline Location & & & & & & & \\
\hline Very rural & $9 \%$ & $16 \%$ & $4 \%$ & $7 \%$ & $20 \%$ & $24 \%$ & $9 \%$ \\
\hline Rural & $9 \%$ & $14 \%$ & $4 \%$ & $9 \%$ & $17 \%$ & $25 \%$ & $10 \%$ \\
\hline Medium & $8 \%$ & $15 \%$ & $5 \%$ & $8 \%$ & $12 \%$ & $29 \%$ & $11 \%$ \\
\hline Urban & $10 \%$ & $16 \%$ & $7 \%$ & $10 \%$ & $10 \%$ & $23 \%$ & $11 \%$ \\
\hline Very urban & $8 \%$ & $21 \%$ & $10 \%$ & $14 \%$ & $6 \%$ & $21 \%$ & $10 \%$ \\
\hline Religion & & & & & & & \\
\hline No religion & $11 \%$ & $18 \%$ & $7 \%$ & $12 \%$ & $5 \%$ & $27 \%$ & $12 \%$ \\
\hline Catholic & $10 \%$ & $14 \%$ & $3 \%$ & $7 \%$ & $24 \%$ & $25 \%$ & $12 \%$ \\
\hline Protestant & $4 \%$ & $8 \%$ & $5 \%$ & $5 \%$ & $27 \%$ & $19 \%$ & $5 \%$ \\
\hline Muslim & $4 \%$ & $48 \%$ & $7 \%$ & $6 \%$ & $3 \%$ & $14 \%$ & $0 \%$ \\
\hline $\begin{array}{l}\text { Source: author } \\
\text { Note: the table } \\
\text { by selected indi } \\
\text { received greate } \\
\text { correspond to th }\end{array}$ & w-ince & $\begin{array}{l}\text { tch elec } \\
\text { of vote } \\
\text { the } 20 \\
\text { e and lo } \\
\text { and ma }\end{array}$ & $\begin{array}{l}\text { ral surv } \\
\text { receive } \\
\text {-2017 } \\
\text { er-educ } \\
\text { hot mat }\end{array}$ & $\begin{array}{l}\text { riod. T } \\
\text { ed vot } \\
\text { exactl }\end{array}$ & $\begin{array}{l}\text { in Du } \\
\text { SP a } \\
\text { Tot } \\
\text { fficia }\end{array}$ & $\begin{array}{l}\text { politica } \\
\text { PVV bo } \\
\text { te shar } \\
\text { ction re }\end{array}$ & $\begin{array}{l}\text { irties } \\
\text { ts. }\end{array}$ \\
\hline
\end{tabular}


Figure 7 - Election results in Switzerland, 1947-2019

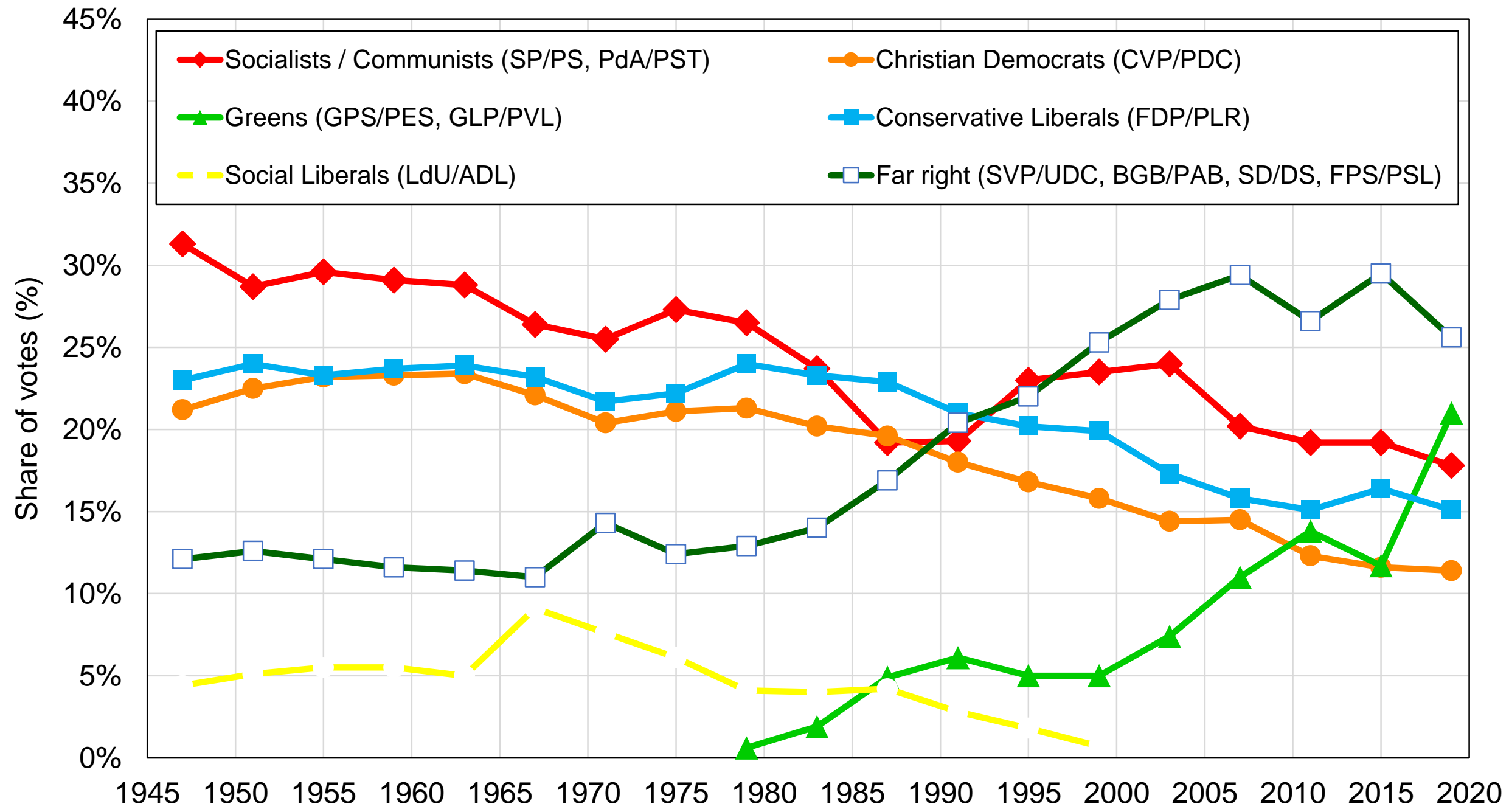

Source: authors' computations using official election results.

Note: the figure shows the share of votes received by selected political parties or groups of parties in federal elections held in Switzerland between 1947 and 2019. Far-right parties received 26\% of votes in 2019. 


\section{Figure 8 - The emergence of a multi-elite party system in Switzerland, 1967-2019}

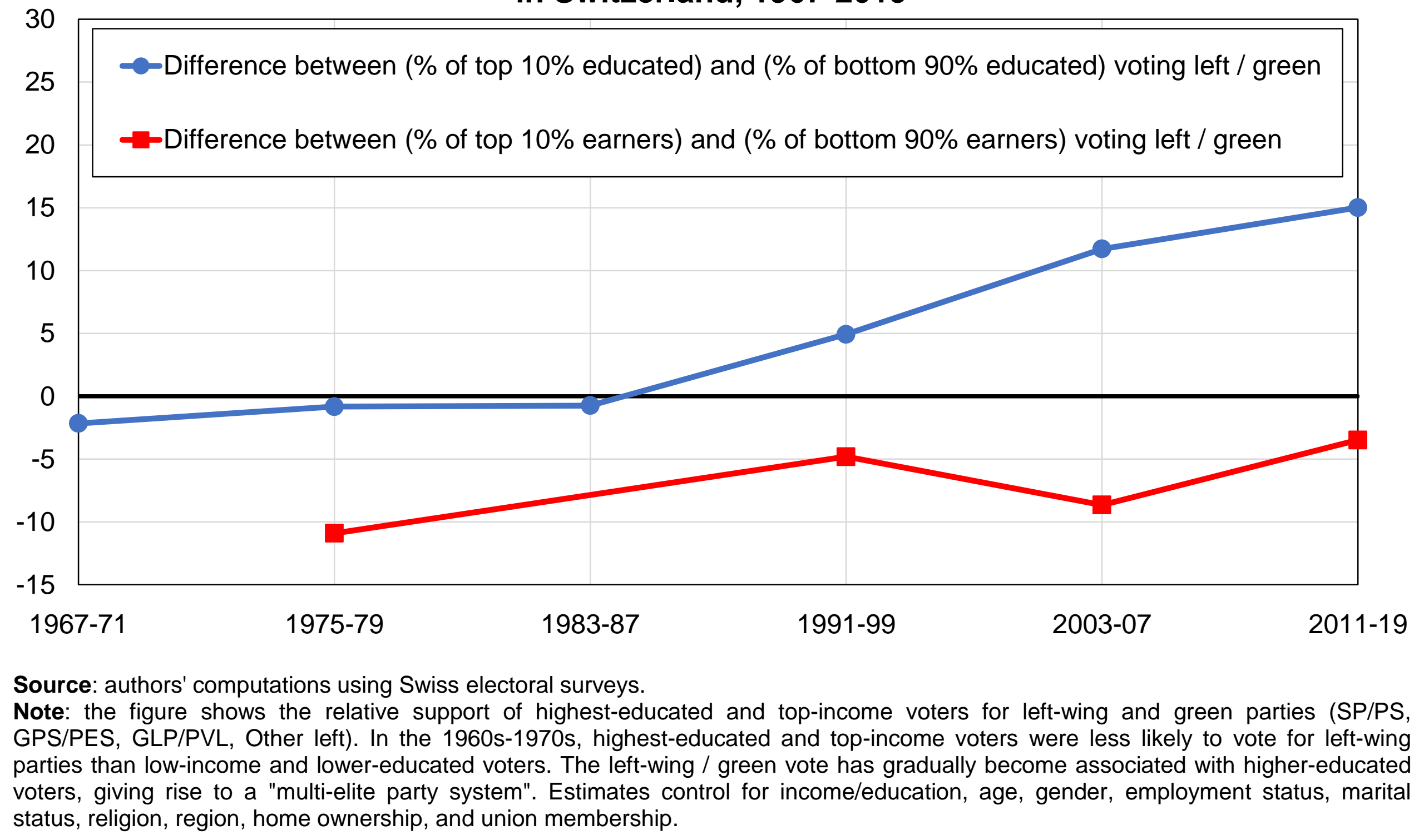




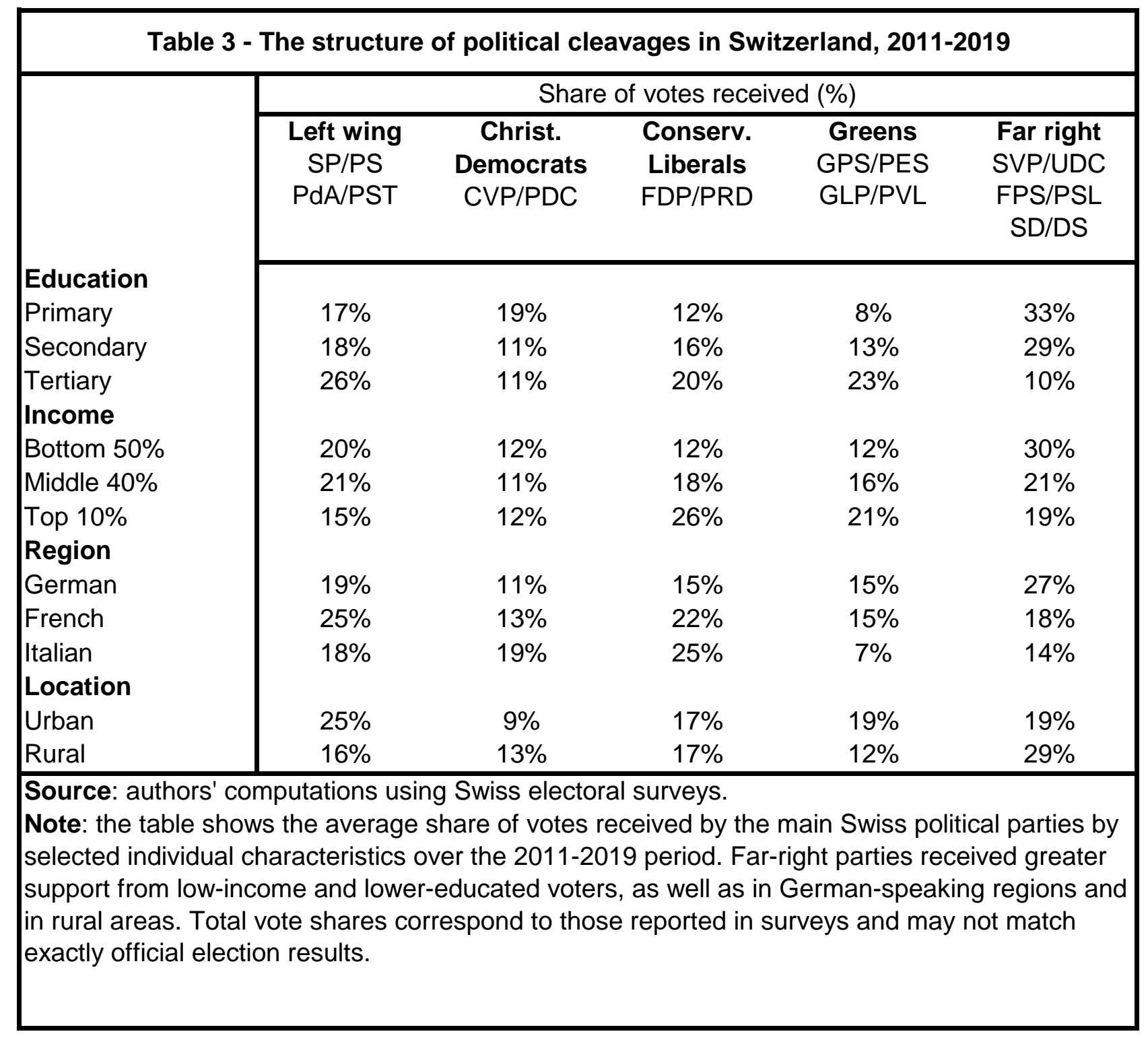


Figure 9 - Election results in Austria, 1945-2019

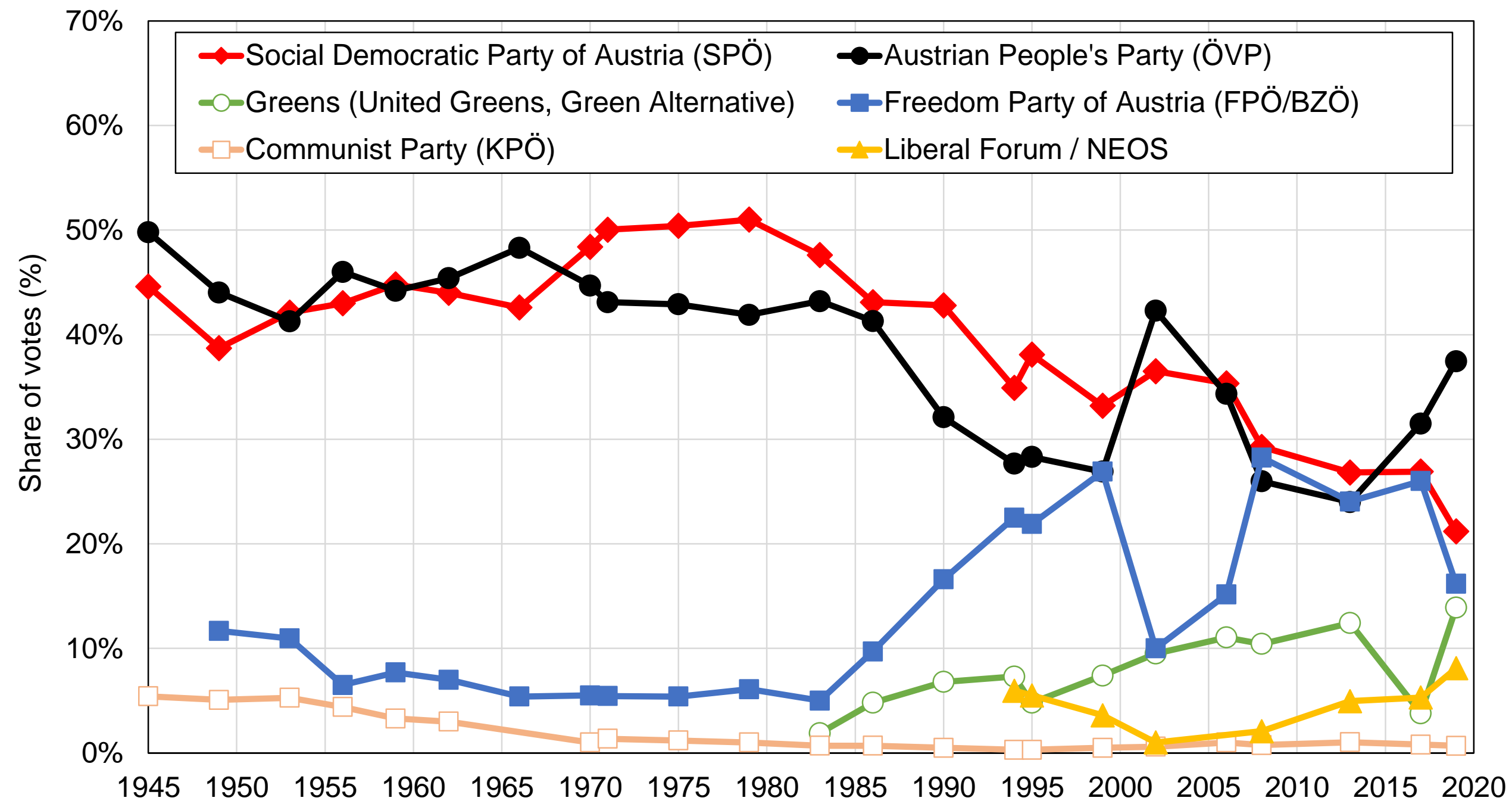

Source: authors' computations using official election results.

Note: the figure shows the share of votes received by selected political parties or groups of parties in general elections held in Austria between 1945 and 2019. The Social Democratic Party received 21\% of votes in 2019. 


\section{Figure 10 - The emergence of a multi-elite party system in Austria, 1971-2017}

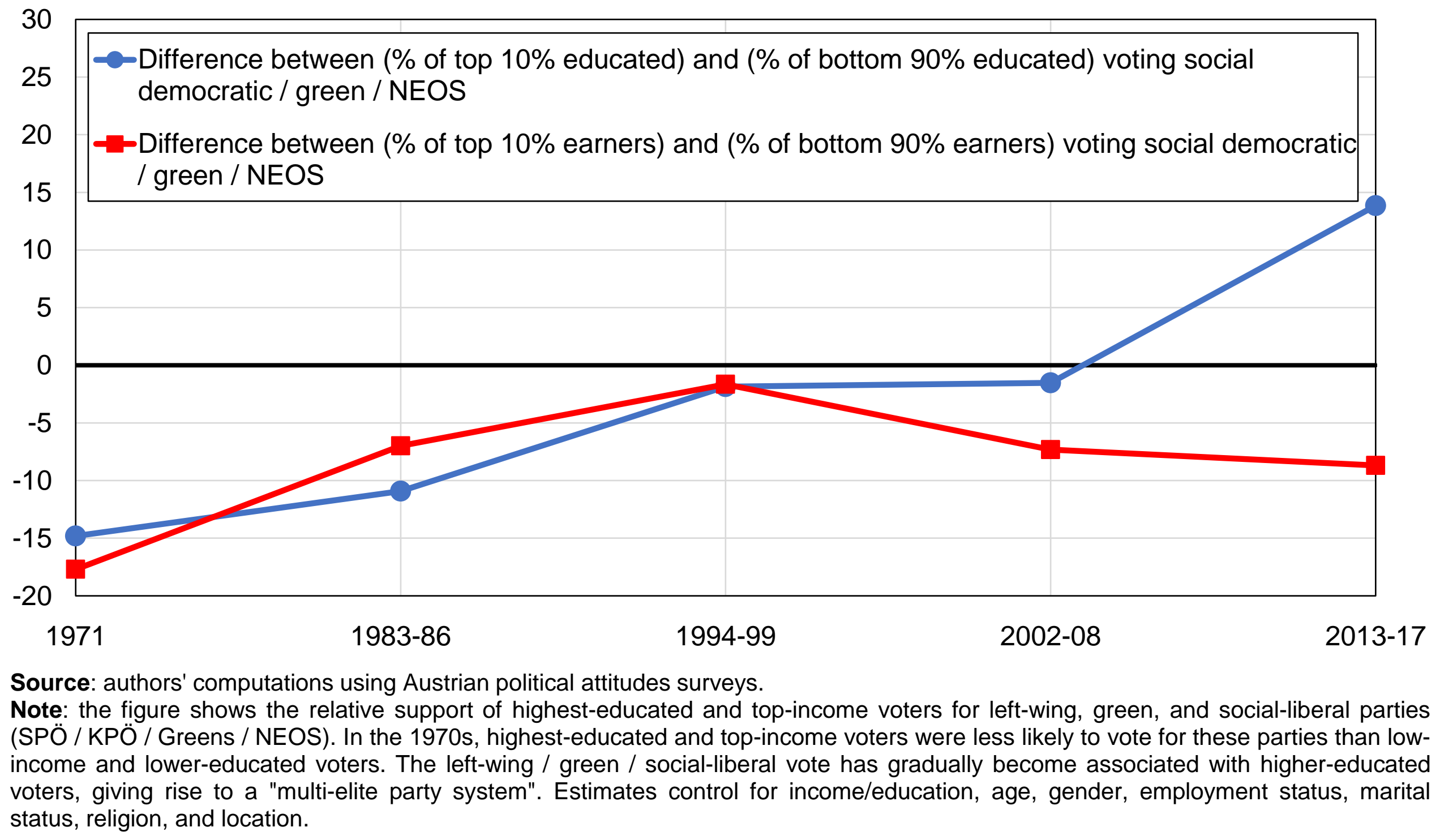


Table 4 - The structure of political cleavages in Austria, 2013-2017

\begin{tabular}{|l|ccccc|}
\hline & \multicolumn{5}{|c|}{ Share of votes received (\%) } \\
\cline { 2 - 6 } & SPÖ / KPÖ & Greens & NEOS & ÖVP & FPÖ / BZÖ \\
\cline { 2 - 6 } Education & $33 \%$ & $5 \%$ & $4 \%$ & $31 \%$ & $25 \%$ \\
Primary & $29 \%$ & $7 \%$ & $5 \%$ & $31 \%$ & $26 \%$ \\
Secondary & $26 \%$ & $21 \%$ & $11 \%$ & $34 \%$ & $5 \%$ \\
Tertiary & & & & & \\
Income & $35 \%$ & $6 \%$ & $5 \%$ & $27 \%$ & $23 \%$ \\
Bottom 50\% & $27 \%$ & $11 \%$ & $6 \%$ & $32 \%$ & $22 \%$ \\
Middle 40\% & $20 \%$ & $12 \%$ & $8 \%$ & $43 \%$ & $14 \%$ \\
Top 10\% & & & & & \\
Location & $33 \%$ & $11 \%$ & $7 \%$ & $26 \%$ & $20 \%$ \\
Urban & $25 \%$ & $7 \%$ & $4 \%$ & $37 \%$ & $25 \%$ \\
Rural & & & & & \\
Religion & $38 \%$ & $14 \%$ & $8 \%$ & $13 \%$ & $21 \%$ \\
No religion & $24 \%$ & $8 \%$ & $5 \%$ & $39 \%$ & $23 \%$ \\
Catholic & $35 \%$ & $10 \%$ & $7 \%$ & $25 \%$ & $23 \%$ \\
Protestant & $66 \%$ & $2 \%$ & $18 \%$ & $10 \%$ & $4 \%$ \\
Muslim & $2 \%$ & & \\
\hline Source: authyyyyy
\end{tabular}

Source: authors' computations using Austrian political attitudes surveys.

Note: the table shows the average share of votes received by the main Austrian political parties by selected individual characteristics over the 2013-2017 period. Left-wing parties (SPÖ / KPÖ)

received greater support from low-income and lower-educated voters, as well as in urban areas.

Total vote shares correspond to those reported in surveys and may not match exactly official election results. 